Review

\title{
Epitope Specificity of Anti-Citrullinated Protein Antibodies
}

\author{
Nicole H. Trier * and Gunnar Houen * \\ Department of Autoimmunology and Biomarkers, Statens Serum Institut, Artillerivej 5, \\ 2300 Copenhagen S, Denmark \\ * Correspondences: nhp@ssi.dk (N.H.T.); gh@ssi.dk (G.H.); \\ Tel./Fax: +45-3268-3268 (N.H.T.); +45-3268-3268 (G.H.)
}

Academic Editor: Christiane Hampe

Received: 30 November 2016; Accepted: 22 February 2017; Published: 8 March 2017

\begin{abstract}
Anti-citrullinated protein antibodies are primarily associated with a progressive course in the autoimmune disease rheumatoid arthritis, a disease with a chronic and inflammatory nature. These antibodies do not appear to have any strict dependency for reactivity except from the presence of the non-genetically encoded amino acid citrulline, which is the result of a posttranslational modification, catalyzed by calcium-dependent peptidylarginine deiminase enzymes. Nevertheless, several amino acids surrounding the citrulline residue notably influence antibody reactivity, especially with a central-Cit-Gly-motif being essential for antibody reactivity. Most importantly, these antibodies have been proposed to be divided into two groups, based on their ability to recognize multiple citrullinated peptides. Thus, an "overlapping" antibody group, which appears to recognize several citrullinated peptides, and a "non-overlapping" antibody group, which only recognizes a limited number of citrullinated peptides, have been proposed. Based on these findings, we suggest that antibodies recognizing several citrullinated targets, also referred to as cross-reactive antibodies, primarily are backbone-dependent, whereas less cross-reactive antibodies primarily depend on the side chains of the amino acids comprising the epitopes for stable antibody-antigen interactions, which reduces the degree of cross-reactivity significantly. Clarifying the reactivity pattern of anti-citrullinated protein antibodies may contribute to determining their true nature of origin.
\end{abstract}

Keywords: anti-citrullinated protein antibodies; citrullinated epitopes; rheumatoid arthritis; cyclic citrullinated peptides

\section{Introduction to Anti-Citrullinated Protein Antibodies}

\subsection{Citrullination of Proteins by Peptidylarginine Deiminases}

Rheumatoid arthritis (RA) is a systemic autoimmune disease characterized by chronic inflammation in the synovial joints, which ultimately may lead to joint destruction and erosion of the underlying bone [1]. One of the most important serological discoveries in rheumatology has been the identification of autoantigens in RA, containing epitopes with the non-genetically encoded amino acid citrulline (Cit) [2,3]. Cit is a post-translationally modified, deiminated derivative of Arg, which originally was named after the watermelon Citrullus vulgaris, which contains a large amount of free Cit. The process of citrullination, or deimination, involves the enzymatic conversion of Arg-containing proteins, which usually occurs during inflammatory processes [4]. Citrullination is catalyzed by peptidylarginine deiminase enzymes (PADs), which are calcium-dependent metalloenzymes, belonging to the superfamily of guanidino group-modifying enzymes [4]. Under physiological conditions, PAD enzymes are normally inactive due to low concentrations of intracellular calcium. Once activated, as a result of elevated calcium levels, the PAD enzymes citrullinate a range of 
cytoplasmic, nuclear, membrane and mitochondrial proteins [5]. In this process, the positively charged guanidino group of Arg is replaced with the neutral ureido group, as depicted in Figure 1. The result of this conversion is a very small change in molecular mass and the loss of a positive charge. This apparently "small" change in the amino acid side chain has a profound effect on intramolecular and intermolecular interactions, as ionic and hydrogen bond interactions are influenced, which changes the isoelectric potential of the proteins leading to structural unfolding, thereby causing more open configurations for the proteins and proteolytic degradation [6].

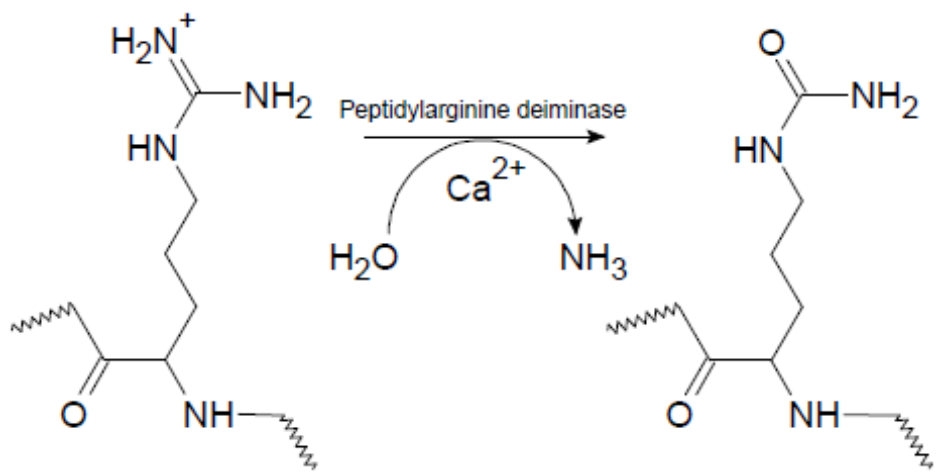

Figure 1. Citrullination (deimination) of peptidylarginine catalyzed by peptidylarginine deiminase in a calcium-dependent process. The positively charged guanidino group is replaced with the neutral ureido group.

Citrullination of proteins normally occurs in cells undergoing apoptosis, where citrullinated proteins are cleared from the body and not encountered by the immune system. In this process, unlimited influx of extracellular calcium activates PAD enzymes, as calcium levels become higher than the resting physiological concentration [7]. Citrullination marks intracellular proteins for degradation with a complete loss both of the polymerization competence of the intermediate filament proteins and of the filament-forming ability [8]. Following citrullination, apoptotic bodies are engulfed by phagocytes, thereby preventing inflammatory reactions. However, in RA, citrullinated proteins are not effectively cleared. In fact, a dysregulation of apoptosis eventually in combination with the ineffective clearance of apoptotic material is suspected to be involved in the accumulation of dying cells and the exposition of autoantigens in RA [9]. Consequently, citrullinated proteins are exposed to the immune system, leading to the generation of citrulline-specific antibodies [10]. This is supported by studies describing that the impaired apoptosis of RA fibroblast-like synoviocytes is pivotal in the establishment of the inflammatory process [11].

In this process, an increase in PAD2 and PAD4 enzyme levels is often observed [7,12]. The role of PAD in the onset of RA has been examined, and recently, a model for PAD infiltration into the synovial joints of RA patients was presented, where the PAD2 and PAD4 enzymes, expressed in monocytes and macrophages, are recruited to the joints [13]. These studies described that the activated cells, containing unstimulated PADs, eventually undergo apoptosis where the PADs are activated as a result of elevated calcium levels. Activation of PAD results in the citrullination of proteins, after which PAD enzymes diffuse out of the cell to citrullinate extracellular proteins. For example, PAD2 and PAD4 enzymes have been reported to citrullinate fibrin in the affected joints. Nevertheless, antibodies to citrullinated proteins have been reported to be present in the sera several years before the clinical symptoms of RA appear [14,15]; hence, the dysregulated PAD activity is potentially disease-initiating. It is currently not known what causes PADs to become dysregulated, but several scenarios may lead to abnormal levels of citrullinated proteins. e.g., PAD activity may become uncontrolled at high calcium concentrations and may lose target specificity, which would result in the extensive modification of arginine-rich proteins and ultimately the loss of activity [7]. Increased levels of PAD enzymes could also explain the elevated levels of citrullinated proteins; however, it is unknown what might cause 
increased translation [7,12]. Moreover, it has been proposed that calreticulin interacts with components of the immune system and promotes immune dysregulation [16-18]. Calreticulin is essential for the clearance of dying cells and has been reported to act as a signal-transducing receptor for the shared epitope (SE) found in RA-associated major histocompatibility complex (MHC) class II molecules [19].

\subsection{Physiological Functions of Citrullination}

Although typically occurring under inflammatory conditions, citrullination has several physiological roles, e.g., citrullination has a role in brain development, female fertility, hair formation and regulation of gene expression via chromatin remodeling, as presented in Table 1 [20-23]. Citrullination of p53 and the estrogen receptor is essential for the regulation of these proteins in the p53- and estrogen-associated pathways [24-30]. Moreover, citrullination is involved in skin keratinization and several immune functions [7,31-36]. In skin keratinization, citrullination of keratin alters the protein structure, enabling proteins to bind to it, which ultimately results in the generation of a protective matrix in the skin [7]. In addition, citrullination of myelin basic protein is important in the function of the myelin sheath, as well as in the plasticity of the central nervous system [7]. In immune functions, citrullination is involved in the function of chemokines and cytokines and it participates in antibacterial neutrophil extracellular trap (NET) formation [37].

Table 1. Physiological functions of citrullination mediated by peptidylarginine deiminases.

\begin{tabular}{cc}
\hline Physiological Functions of Citrullination & References \\
\hline Skin keratinization & {$[7]$} \\
Brain development & {$[7,21]$} \\
Fertility & {$[20]$} \\
Hair formation & {$[22]$} \\
NET formation & {$[37]$} \\
Gene regulation & {$[24-30]$} \\
Immune functions & {$[7,33-36]$} \\
\hline NET, neutrophil extracellular trap.
\end{tabular}

As presented in Table 1, the process of citrullination is not specific to RA; however, an aberrant $B$ cell response against citrullinated epitopes may be specific to RA. Moreover, other rheumatologic diseases with synovitis, including inflammatory osteoarthritis, reactive arthritis, undifferentiated arthritis, gout and even trauma, and in rare cases healthy individuals as well, are occasionally associated with the presence of antibodies to citrullinated proteins [38-40]. Nevertheless, these antibodies are detected in a very small percentage of cases as compared to RA; thus, antibodies to citrullinated proteins are specific diagnostic and prognostic markers in RA [41].

\subsection{Characteristics of Anti-Citrullinated Protein Antibodies}

Antibodies recognizing the post-translationally modified amino acid Cit are referred to as anti-citrullinated protein antibodies (ACPA). These antibodies are primarily directed to citrullinated proteins located in the joints or present in circulation [42-44]. Moreover, recent studies have reported that ACPA occasionally are enriched in the lung as well, early in the development of RA [45].

ACPAs belonging to different immunoglobulin classes have been identified [46,47]. Although ACPAs predominantly are of the IgG class, IgM and IgA classes are present as well. Consequently, several commercial assays are available, which primarily detect the presence of ACPA IgG, whereas one assay detects the presence of $\operatorname{IgA}$ and $\mathrm{IgG}$, reportedly yielding a higher assay sensitivity. Although the ACPA IgM antibodies especially are short-lived, IgM reactivity responses have been characterized [48]. Interestingly, the antibody isotype appears to influence the reactivity of ACPA responses, as it has been reported that ACPA IgM responses are different from ACPA IgG responses [48]. Similarly, the ACPA response against one citrullinated antigen is different from the immune response against another citrullinated protein. Elucidation of the mechanisms behind these observations could be of relevance to the identification of the true citrullinated antigens that drive ACPA responses [48]. 
The presence of ACPAs is associated with poor disease outcomes, such as increased disease activity, radiographic progression, disability and increased mortality [49-52]. In addition, studies find that the presence of ACPA in patients with early arthritis predicts disease progression, as ACPA-positive RA is more severe and progressive than ACPA-seronegative RA [52-54].

The search for autoantigens associated with RA disease pathogenesis and the diagnosis of RA has resulted in the characterization of several citrullinated proteins and the development of several assays for detection of ACPA, which is a major breakthrough in the laboratory diagnostics of RA [55]. As a result, several types of ACPAs have been identified, as seen in Table 2. An ACPA originally reported in 1964 was the anti-perinuclear factor antibody [56]. Another ACPA, the anti-keratin antibody, was discovered in 1979 in RA sera [57]. Both antibodies recognize the cyto-keratin filament-aggregating protein filaggrin [58-60]. Nevertheless, as epidermal filaggrin is not expressed in the joints, it cannot be considered as a joint-specific autoantigen that drives an anti-filaggrin response. Thus, the antibody response should be the result of a cross-reaction against unknown proteins expressed in the joint. Another highly specific autoantibody discovered in 1994 was the anti-Savoie (anti-Sa) antibody [61,62]. The reactivity of Sa antibodies to citrullinated vimentin, defining them as ACPAs, was recently demonstrated [13]. Finally, a mutated and citrullinated version of vimentin has been used in a recently developed enzyme-linked immunosorbent assay (ELISA) for detection of anti-mutated citrullinated vimentin antibodies, anti-MCV [63]. Cyclic citrullinated peptide (CCP) antibodies were reported in 2000, and were named based on the reactivity in an ELISA using synthetic CCPs [64]. The sensitivity of the first generation anti-CCP test was further increased with the development of the CCP2, СCP3 and CCP3.1 tests [65-68]. Dependent on the type of antibody, varying levels of sensitivity and specificity are found in these assays, as shown in Table 2.

Table 2. Specificity and sensitivity of anti-citrullinated protein antibodies.

\begin{tabular}{cccc}
\hline Antibody & Specificity & Sensitivity & Reference \\
\hline Anti-perinuclear factor & 90 & $50-70$ & {$[68]$} \\
Anti-keratin antibodies & 94 & 45 & {$[69]$} \\
Anti-citrullinated filaggrin & $>90$ & 60 & {$[70]$} \\
Anti-citrullinated fibrinogen & $>90$ & 55 & {$[71]$} \\
Anti-fibrin & 90 & 75 & {$[72]$} \\
Anti-CCP1 & 96 & 53 & {$[63]$} \\
Anti-CCP2 & $94-95$ & $68-74$ & {$[73,74]$} \\
Anti-CCP3 & $86-96$ & $68-79$ & {$[67,73-75]$} \\
Anti-CCP3.1 & 98 & 83 & {$[74]$} \\
Anti-Sa antibodies & 99 & 43 & {$[76]$} \\
Anti-mutated citrullinated vimentin & 97 & 72 & {$[77]$} \\
Anti-citrullinated EBNA-1 & 85 & 67 & {$[78,79]$} \\
\hline
\end{tabular}

CCP, cyclic citrullinated peptide; EBNA, Epstein-Barr nuclear antigen; Sa, Savoie.

ACPAs are found in approximately 70\% of RA cases and can be detected up to 14 years before the onset of disease $[14,15,80,81]$. Consequently, ACPAs were included in the 2010 American College of Rheumatology/European League Against Rheumatism classification criteria for RA [82], in contrast to the previous 1987 criteria, where the rheumatoid factor was the sole serological marker [83].

Routine testing for ACPAs is commonly performed by using a commercial anti-CCP2 ELISA. However, where the CCP1 assay is based on a filaggrin-derived peptide, the CCPs used in the CCP2 assay reportedly do not correspond to any human protein sequence, and thus the CCP2 antibodies only act as surrogate markers for autoimmunity in RA without formally defining any reactivity against autoantigens present in vivo.

Despite up to $70 \%$ of RA sera being estimated to be ACPA-positive, the absolute concentration of ACPA in serum currently remains unknown. The CCP2 assay, which currently is regarded as the golden standard assay, occasionally determines RA sera as ACPA-negative; however, it has been estimated that approximately $5 \%-8 \%$ of these sera in fact are ACPA-positive $[79,84-86]$. 


\subsection{Pathogenesis of Rheumatoid Arthritis}

In general, the pathogenesis of RA involves a number of cellular responses. Autoimmune responses mediated by $\mathrm{T}$ and $\mathrm{B}$ cells are important in the initiation of the inflammatory cascade. Then $\mathrm{T}$ cells, B cells, macrophages and neutrophils migrate into synovial tissues, where they, among others, produce proteases that destroy the extracellular matrix, in particular that of cartilage. As a result, synovial hypertrophy and angiogenesis occur, leading to cartilage destruction as well as osteoclast activation and ultimately bone erosion [87].

It has been a matter of much debate whether ACPAs play a role in the pathogenesis of RA, although the etiology of the disease remains unknown [88-90]. Using animal models it has been found that transfer of monoclonal antibodies recognizing citrullinated collagen or fibrinogen exacerbate inflammatory arthritis [90]. Moreover, ACPAs have been reported to be able to activate both FcR-positive cells and the complement system [91,92]. In addition, ACPAs are associated with a progressive disease course and a poor outcome [49-52]. Finally, the efficacy of (memory) B cell depletion in treating RA patients using a monoclonal anti-CD20 antibody (Rituximab) and the effect of plasmapheresis (in combination with TNF- $\alpha$ inhibitors and disease-modifying anti-rheumatic drugs (DMARDS) may suggest a pathogenic role of ACPAs $[88,89,93,94]$. Collectively, these findings argue that ACPAs could play a role in RA disease pathogenesis. Nevertheless, the long presence of ACPAs prior to the onset of the disease may indicate that the antibodies are not involved in the actual pathogenesis. Rather it has been proposed that ACPAs are associated with inflammation in the joints, as ACPAs in the inflamed synovium have been shown to be associated with citrullinated antigens forming immune complexes, resulting in progression of the inflammatory process [95]. These findings suggest that there is no target injury in the absence of citrullinated target antigens, but when these antigens are present, ACPAs can greatly amplify inflammation and damage. These findings are in accordance with the observation that ACPA-negative RA usually experiences a mild disease course, whereas ACPA-positive RA often experiences progressive disease and poor outcomes [49-52]. Finally, these findings are supported by an ex vivo study reporting that ACPA-containing immune complexes stimulate pro-inflammatory cytokine production in macrophages [91].

Only limited information is available in relation to citrulline-specific T cells in RA [96]. RA is thought to be a T cell-mediated disease, based on its strong association with human leukocyte antigen (HLA) class II alleles, clinical responsiveness to T cell-directed therapies and the presence of $\mathrm{T}$ cells in the synovium of early RA patients and in multiple joints [96-98]. Previous studies have demonstrated enhanced binding and presentation of citrullinated peptides by shared epitope (SE) HLA-DR and enhanced in vitro $T$ cell responses directed against individual citrullinated epitopes [99-103]. Recent findings indicate that citrulline-specific Th1 cells are enriched in RA patients [96] and that T cells recognize citrullinated epitopes derived from multiple synovial antigens [103-105].

\subsection{Rheumatoid Arthritis Risk Factors}

As mentioned previously, the etiology of RA remains to be determined. Based on twin studies it has been proposed that the relative contribution of genetic variation to develop RA is $50 \%-60 \%[106,107]$. The strongest evidence for the influence of genetic factors on RA onset relates to MHC class II antigens, and, in particular, to various HLA alleles, the most important of which is the MHC II structure defined by the SE [108]. In fact, it has been estimated that up to $50 \%$ of RA patients are SE-positive [105]. Stastny originally documented an association between HLA-DR4 (HLA-DRB1*04) and the risk of developing RA [108]. A discrepancy in the association of different HLA-DRB1 genes revealed the presence of a conserved hexapeptide sequence in the third hypervariable region of all RA-associated HLA-DRB1 alleles, involving positions 69-74 "EQK/RRAA", also referred to as the SE [108]. The mechanism underlying the SE-RA association remains unclear; a common hypothesis attributes it to the presentation of arthritogenic antigens or T cell repertoire selection [109-111]. Moreover, studies by Kapitany and Snir found a significant correlation between HLA-DR4 and HLA-DRB1 and the 
ACPA titers, respectively [112,113]; hence it has been concluded that HLA-DR4 and HLA-DRB1 allele positivity poses an increased risk for developing RA because of their association with high ACPA titers.

Another genetic factor that is associated with increased risk of RA is the protein tyrosine phosphatase non-receptor type 22 (PTPN22). The PTPN22 gene encodes a tyrosine phosphatase, which is essential in T cell signaling [114,115].

In general, the currently known genetic risk factors associated with RA are thought to be specifically associated with either ACPA-positive or ACPA-negative disease. Thus, ACPA-positive RA has been found to be closely linked to the presence of HLA-DRB1 alleles containing SE motifs $[116,117]$ and polymorphisms in the PTPN22 gene $[115,118,119]$. Moreover, ACPA-positive status has been suggested to be associated with the recently identified, but modest genetic risk factor TRAF1-C5 [120]. Other genetic factors such as variations in the interferon-regulating factor IRF-5 and polymorphisms in a newly identified risk gene in the C-type lectin complex have been suggested to be associated with ACPA-negative RA disease [121,122].

Further findings by Klareskog and colleagues showed that in HLA-DR-positive patients, cigarette smoking triggers the formation of ACPAs [116]. More recently, it has been shown that HLA-DRB1 SE, PTPN22 polymorphism and cigarette smoking together associate more significantly with ACPA reactivities than with anti-CCP levels, indicating that genetic as well as environmental factors are essential and interact with each other. Based on these findings, it has been proposed that further genetic analysis will allow for the separation of RA into subgroups, where each has specific risk factors and disease course $[85,123]$.

\section{Citrullinated Epitope Characteristics}

Examples of reported citrullinated proteins associated with RA are, among others, fibrin, fibrinogen, enolase, collagen, vimentin and EBNA [124-129]. Currently, no dominant epitope has been identified among the citrullinated proteins, although it is evident that the number of citrullinated epitopes is limited initially, but increases over time. Once the disease has been diagnosed, the number of recognized epitopes remains stable [130]. This process of epitope spreading occurs prior to the onset of RA [80,130].

It is well established that ACPAs are directed to various citrullinated epitopes, in which not only Cit but also flanking amino acids are essential for antibody recognition [3,131,132]. Nevertheless, thorough analysis of citrullinated epitopes reveals no conclusive epitope pattern, and thus several citrullinated epitopes have been identified, as presented in Table 3.

Table 3. Reactive anti-citrullinated protein antibody epitopes.

\begin{tabular}{ccccc}
\hline Protein & Epitope & $\begin{array}{c}\text { No of Cit } \\
\text { Residues }\end{array}$ & $\begin{array}{c}\text { Most Important } \\
\text { Residue }\end{array}$ & Reference $^{\text {Ref }}$ \\
\hline Enolase & ${ }^{5}$ KIHA-Cit-EFDS-Cit-GNPTVE ${ }^{21}$ & 2 & Cit $^{15}$ & {$[121]$} \\
Fibrin & $\alpha^{36}$ GP-Cit-VVE-Cit-HQSACKDS & 20 & Cit $^{42}$ & {$[73]$} \\
Fibrin & $\beta^{60}$ Cit-PAPPISGGGY-Cit-A-Cit & 2 & Cit $^{74}$ & {$[73]$} \\
Collagen II & 358 GA-Cit-GLTG-Cit-PGDAGPPGPP 375 & 2 & Cit $^{360}$ & {$[44]$} \\
Filaggrin & 306 SHQEST-Cit-G-Cit-SRGRSGRSG ${ }^{324}$ & 2 & Cit $^{312}$ & {$[3]$} \\
EBNA-1 & GGRRGRGRERA-Cit-GGSRERAR & 1 & - & {$[79]$} \\
EBNA-1 & ARGGSRERARGRGRG-Cit-GEKR & 1 & - & {$[79]$} \\
\hline
\end{tabular}

EBNA, Epstein-Barr nuclear antigen.

Original findings analyzing ACPA reactivity described that citrullinated epitopes primarily depend on a combination of Cit with small neutral amino acid residues such as Ser or Gly, often in combination with Val, His or Thr [2,3,128,132-134]. Recent findings do, however, indicate that primarily the-Cit-Gly-motif is essential for antibody reactivity, as illustrated in Figure 2. Using 20-mer ovalbumin peptides containing Arg- $\mathrm{Xxx}$ residues in the center, the following substitutions of -Arg-Gly-, Cit- $\mathrm{Xxx}_{\mathrm{x}-\text {, }}$ and -Cit-Gly- were introduced to examine the effect of the Cit-Gly motif. As seen in Figure 2a, only the peptides containing the Cit-Gly motif obtained significant antibody reactivity [131]. These findings were confirmed by Ala scanning studies, where antibody reactivity to substituted pro-filaggrin peptides 
was analyzed. Using a 14-mer citrullinated pro-filaggrin peptide as a template, we found that all amino acids could be substituted with Ala without reducing antibody reactivity, except from the central Cit-Gly motif $[133,135]$. Moreover, we found that antibody reactivity was significantly reduced when substituting Gly in the Cit-Gly motif with other amino acid residues such as Ser, Thr, His, Pro, Trp and Val, as illustrated in Figure 2b [131]. Furthermore, it has been reported that the N-terminal position next to Cit and the second and third position C-terminal to Cit are irrelevant for antibody reactivity, as several amino acids are tolerated in these positions [131]. In addition to a Cit-Gly motif, the presence of positively charged amino acids C-terminal to Cit does appear to stimulate interaction, as peptides containing a Cit-Gly motif in combination with a positively charged residue in the C-terminal yield higher sensitivities $[44,84,135,136]$. Thorough characterization of a Fab-collagen peptide complex (A-Cit-GLTGRPGDA) performed by Uysal and colleagues confirmed that $\mathrm{Cit}$ and a C-terminal Arg are essential for reactivity, as the side chains of these residues are involved in most of the interactions with the antibody [44].

(a)
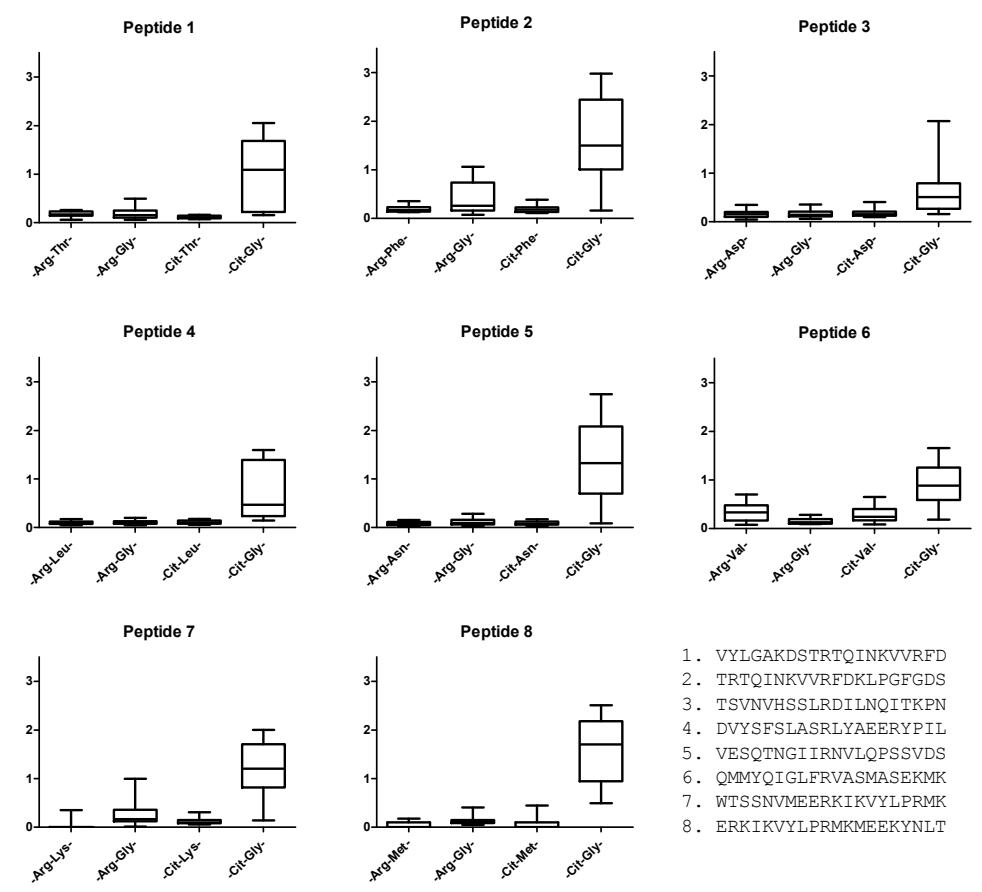

(b)

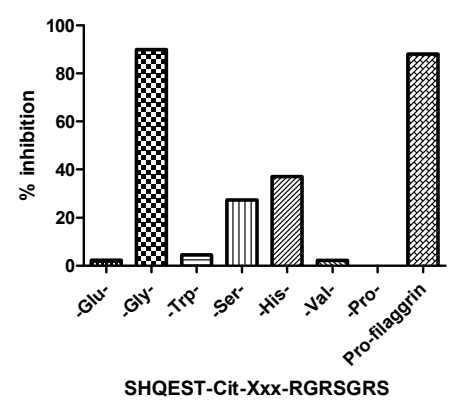

Figure 2. Anti-citrullinated protein antibody reactivity to substituted citrullinated peptides. (a) ACPA reactivity to substituted 20-mer ovalbumin peptides. Original peptides containing Arg in a central position were used as templates. In the remaining peptides, the Arg-Xxx motif was substituted with Arg-Gly, Cit-Xxx and Cit-Gly; (b) ACPA reactivity to substituted pro-filaggrin peptides. The peptide SHQEST-Cit-GRSRGRS was used as template. In the position C-terminal to Cit, various amino acid residues were introduced (Glu, Gly, Trp, Ser, His, Val, Pro). The 22-mer pro-filaggrin peptide (HQSHQEST-Cit-GRSRGRSGRSGS) was used as control. 
Although the immediate dependency relates to the presence of the central Cit-Gly motif, recent findings indicate that the presence of Pro C-terminal to Cit influences ACPA reactivity negatively, as the presence of Pro in the first, second or third position C-terminal to Cit notably reduces ACPA reactivity, possibly by contributing to a rigid structural conformation [131,133,135].

Although primarily dependent on the citrullinated Cit-Gly motif, this dipeptide is not sufficient for antibody reactivity [133]. Screening the reactivity of antibodies to citrullinated peptides found that at least five amino acids should be present in the citrullinated peptide for it to be recognized $[3,6,137]$. These findings were confirmed by Uysal et al., where analyses of a Fab-peptide crystal structure showed that the Cit residue and seven flanking amino acid residues were essential for reactivity [44]. Further analysis indicates that for optimal ACPA reactivity, the citrullinated peptides should be at least 14 amino acids long [3,133,135].

Several studies have been conducted using multiple citrullinated peptides [128,132,138]. Thus, as presented in Table 3, some ACPA epitopes contain more than one citrullyl residue. Nevertheless, several studies indicate that these residues do not contribute equally to antibody reactivity $[3,72,127,132]$. Often a single residue predominantly contributes to the ACPA reactivity, whereas the remaining residues contribute weakly or not at all.

\section{Citrullinated Epitope Structures}

Only limited information is available on the specific interaction between ACPAs and citrullinated epitopes. It has previously been reported that citrullination of Arg residues by PAD enzymes depends on the conformation of the target protein, which could indicate that the peptide fold may affect the citrullination of the specific Arg residue and ultimately the structure of the citrullinated peptide [139]. Thus, one possibility is that citrullination of proteins mediates distortion, initiating the exposure of neo-epitopes. Another possibility is that removal of the imine group from the Arg side chain may introduce unique specific molecular interactions, which may influence the protein structure [44]. This is in accordance to a theory proposed in 2009, which states that partial unfolding/denaturation by citrullination of particular Arg residues could initiate a mechanism which induces conformational changes of the peptide, resulting in the generation of $\beta$-hairpin structures [44]. However, unless the side chain of Arg directly contributes to an intramolecular ionic interaction, it appears most likely that citrullination results in exposure of neo-epitopes rather than inducing molecular changes.

Early findings hypothesized that since no sequence homology was evident between the citrullinated epitopes, structural homology should be of importance to ACPA antibodies [128]. These findings were primarily based on cross-reactivity analyses between a fibrinogen peptide and a filaggrin-derived peptide antibody [128]. Nevertheless, as no specific residues or groups of residues are favored in specific positions, it seems unlikely that these epitopes are located in specific structures. This is in accordance to recent findings, describing that ACPA antigenicity virtually is obtained with any peptide when introducing a Cit-Gly motif, and that ACPA reactivity primarily depends on the presence of a Cit-Gly motif in combination with a peptide backbone for stable reactivity, rather than a specific secondary structure $[131,135]$. Thus, in order for ACPAs to recognize multiple peptides, in theory, independent of amino acid composition and epitope structure, the peptides are believed to be of flexible nature $[133,135]$.

It has been widely examined whether cyclic or linear epitope structures influence antibody reactivity $[64,84,133,140]$. In the original study by Schellekens et al. (2000), describing the reactivity to the first-generation CCP assay, synthetic CCPs were employed, which obtained higher sensitivity compared to linear versions [64]. Cyclic peptides were used in an attempt to force the peptide to adopt a $\beta$-hairpin conformation, as Cys-bridged peptides have been shown to mimic the $\beta$-turn structure of the antigenic epitope and can bind with enhanced affinity to antibodies $[64,140,141]$. Adoption of a $\beta$-hairpin structure is energetically more stable, and hence it has been proposed that the energetically favored peptide conformation may contribute to the predominance of $\beta$-turns compared with other possible structures in peptide-antibody complexes [142]. In relation to this, cyclization of citrullinated 
peptides has been reported to yield a more stable epitope presentation, which has been verified when conducting competitive inhibition experiments using cyclic and linear peptides [84]. Although cyclic peptides at first glance appear to yield higher ACPA sensitivities [64,137], recent findings indicate that reducing the number of amino acids in the cyclic structure has a profound negative influence on ACPA reactivity $[133,137]$, most likely because the peptides are constrained in a rigid conformation, reducing the flexibility of the peptide $[133,136]$.

Thorough studies performed by Uysal and colleagues characterized the interaction between a panel of mouse monoclonal antibodies generated and a triple helical collagen epitope (aa 359-369; A-Cit-GLTGRPGDA) [44]. Structure analysis of a monoclonal Fab fragment in complex with the citrullinated epitope showed that the citrullinated epitope changes conformation upon interaction with the citrulline-dependent antibody [44] by adopting a non-native $\beta$-hairpin conformation, where the side chain of Cit is exposed into the combining site of the antibody, as shown in Figure 3 . This allows the peptide to have more interactions between the antibody's complementarity-determining region (CDR) loops and the side chains of the amino acids, which contributes to an increased affinity. Moreover, side chains of the Arg and Cit residues are extended outwards in opposite directions, which increases the surface area of the interaction between the antibody and the epitope, as seen in Figure 3. The contact with the Cit residue indicates that an Arg in the same position would not have fitted in [44]. Based on these findings, it was concluded that Cit specificity can be explained by direct interactions, although it was not excluded that citrullination additionally changed the conformational structure of the targeted protein, which may lead to exposure of newly generated neo-epitopes.

Collectively, these findings indicate that peptides of flexible nature, eventually possible of folding into a $\beta$-turn structure, are essential for ACPA reactivity [44,135].

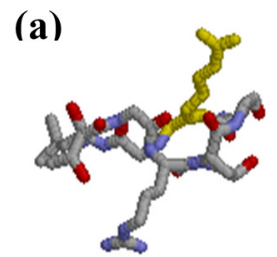

(b)

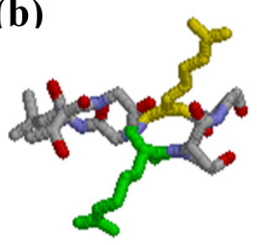

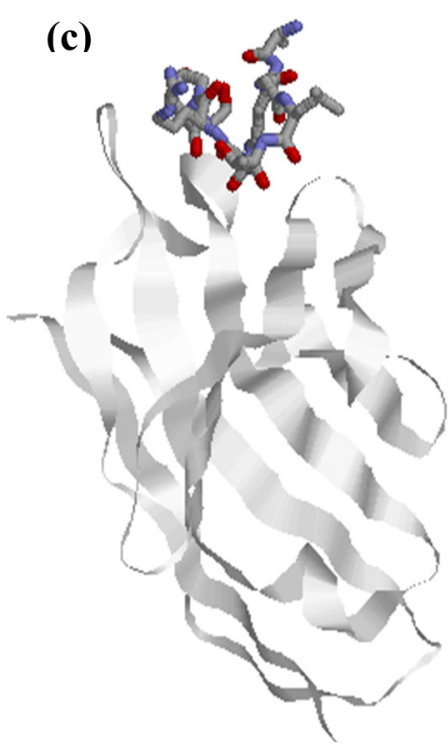

(d)

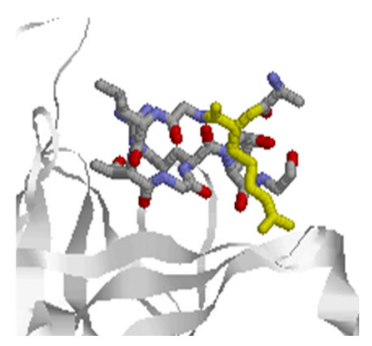

(e)

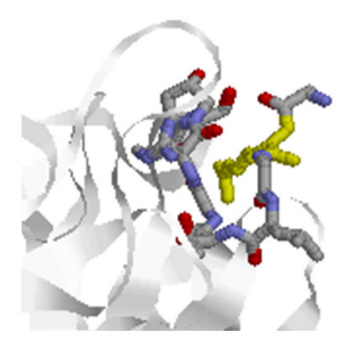

Figure 3. Anti-citrullinated collagen type II antibody in complex with citrullinated collagen II peptide aa 359-369. (a) Location of Cit (yellow) in the selected epitope; (b) Location of Cit (yellow) and Arg (green) extending in opposite directions; (c) Location of the citrullinated epitope in relation to the antigen-binding site of the antibody; (d) Location of Cit in the collagen II peptide relative to the antibody-binding groove; (e) Orientation of Cit into the antibody-binding groove. PDB ID: 2W65 [44].

\section{Anti-Citrullinated Protein Antibody Specificities}

The facts that several citrullinated antigens have been identified in RA and that no immediate homology exists indicate that ACPA responses are cross-reactive, either by being positive for antibodies with different specificities or single antibodies that are true cross-reactors. Moreover, the golden standard for ACPA detection, the anti-CCP2 ELISA, does not contain epitopes from citrullinated 
proteins found in the joints, yet still obtains high antibody reactivity, which supports that these antibody responses indeed are cross-reactive. Thus, although RA sera may have high CCP antibody titers, does this not provide information about the identity of citrullinated proteins, which are recognized by the CCP antibodies.

The principle of ACPA reactivity is depicted in Figure 4. As seen, ACPAs have been reported to recognize a diverse set of citrullinated proteins $[112,143,144]$. However, a small group of ACPAs appear to be less cross-reactive or even epitope-specific; thus, they only recognize a single citrullinated epitope $[79,143,144]$. This makes ACPAs a collection of (partially) cross-reactive antibodies.

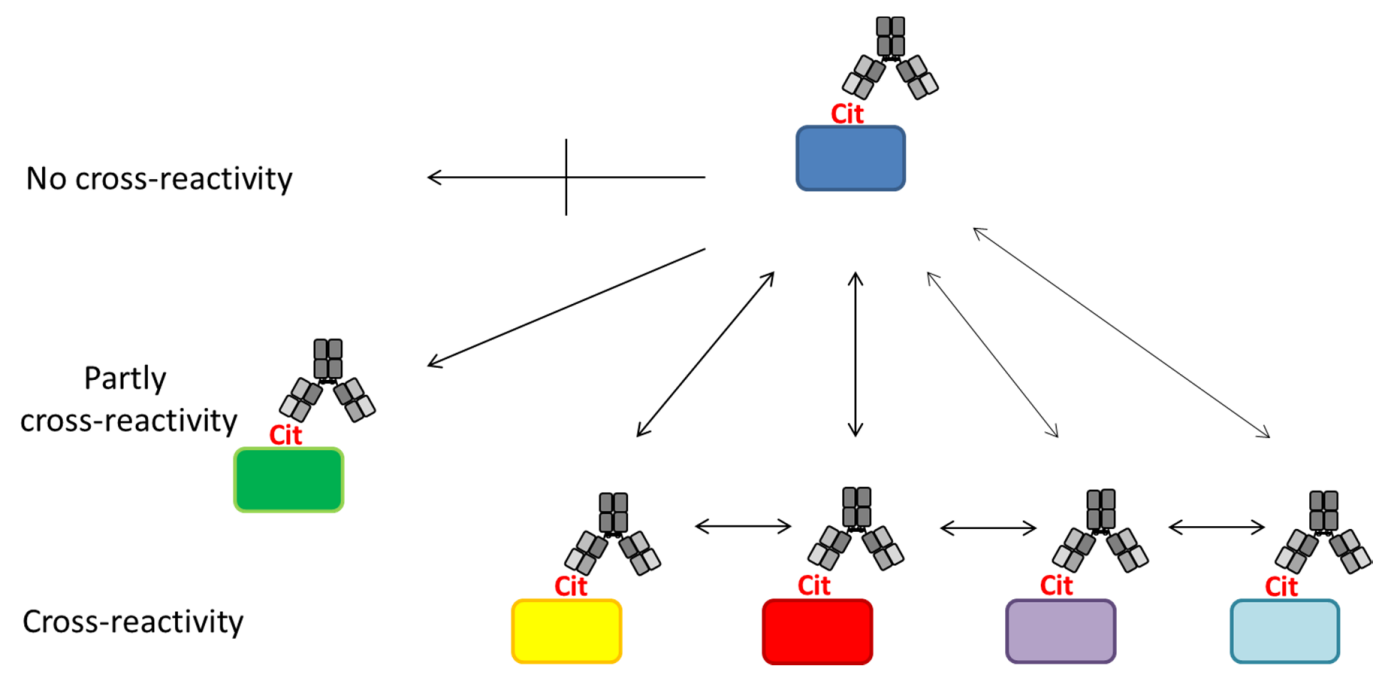

Figure 4. Anti-citrullinated protein antibodies are a collection of partially cross-reactive antibodies recognizing citrullinated targets. ACPA reactivities can be divided into several (partially) cross-reactive fine specificities. Some ACPAs captured by a citrullinated protein cross-react with other citrullinated proteins. A small group of ACPAs appears to have limited or no cross-reactivities. Different colors indicate different proteins.

The degree of cross-reactivity has been analyzed in several studies. In a study by Montes and colleagues, the association between anti-citrullinated vimentin, anti-citrullinated $\alpha$-enolase and CCP2-positivity was determined [145]. Interestingly, only a limited number of sera were found to recognize both peptides. Nevertheless, as the vimentin peptide (aa 60-75) does not contain any Cit-Gly motifs, which have been reported to be essential for reactivity [131], the low cross-reactivity is ascribed to the absence of the motif. Despite this association, it is unclear whether the antibodies recognizing the CCP2 peptides are the same antibodies that recognize citrullinated proteins in the joints. This is a drawback of several studies analyzing ACPA reactivity, as these studies often are based on CCP2-positive sera. In these cases, CCP2-negative RA sera, which may be ACPA-positive, are neglected.

Previous studies have indicated that ACPA reactivity patterns to citrullinated antigens, at the population level, vary between RA individuals $[43,79,112,144]$. In relation to this, different subgroups of ACPA antibodies have been determined, indicating that ACPA responses are highly diverse with respect to the recognition of specific citrullinated epitopes [144]. This could indicate that ACPA responses to citrullinated antigens are non-overlapping and coexist in some individuals. Other studies suggest that these antibody responses at least are partially cross-reactive in a subpopulation of RA individuals $[144,146]$.

Based on a study by Ioan-Facsinay et al. analyzing ACPA reactivity to selected citrullinated peptides, it was concluded that ACPAs are a collection of antibodies that are divided into overlapping and non-overlapping reactivities [143]. Moreover, it was confirmed that the majority of ACPA responses are cross-reactive; however, this cross-reactivity is not complete, as distinct non-cross-reactive responses occasionally are detected in RA patients [143], which is nicely illustrated in Figure 4. These findings 
are in accordance to the fact that cross-reactive antibodies, recognizing multiple epitopes, primarily are dependent on a central Cit motif in combination with a random peptide backbone, as previously described [135]. To study whether non-cross-reactive ACPAs can exist within an individual, we recently determined the cross-reactivity of RA sera $[80,116]$. Using different citrullinated peptides, we found that the degree of cross-reactivity varied and, more importantly, that non-overlapping ACPA responses exist. As depicted in Figure 5a, illustrating the reactivity of RA sera to various citrullinated peptides, $15 \%$ of the RA sera were monospecific to the respective citrullinated EBNA-1 peptides (sera reacting with only one citrullinated peptide) [79]. Furthermore, although a small portion of the RA sera was monospecific, $50 \%$ of the RA sera reacted with more than two citrullinated EBNA- 1 peptides, confirming the theory of overlapping and non-overlapping ACPA reactivities $[47,79]$. Similar findings have been repeated with other citrullinated peptides, e.g., citrullinated fibrinogen, $\alpha$-enolase and collagen, where both cross-reactive and monospecific ACPA responses were identified, as illustrated in Figure 5b [115]. Moreover, it has been verified that patients with RA and various reactivities against one or more citrullinated peptides do not present any difference in their clinical picture or in disease severity [147]. The conclusions are based on reactions of polyclonal patient sera and remain to be verified with larger collections of monoclonal antibodies (which are not available at present). The monoclonal antibodies investigated to date show broad cross-reactivity, reflecting a high backbone dependency (in addition to the central Cit-Gly motif). However, the existence of more specific side chain-dependent antibodies is indicated by the reactivity pattern of patient sera (Figure 5).

(a)

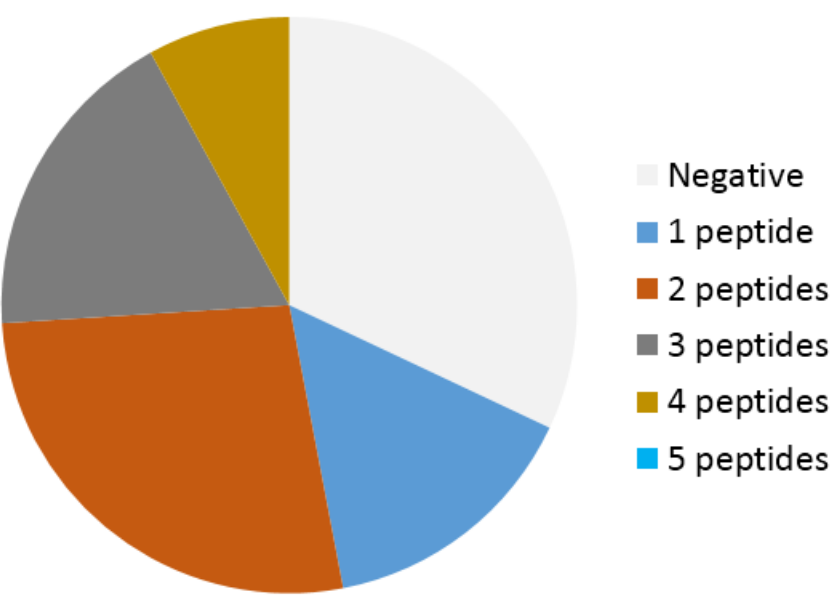

(b)

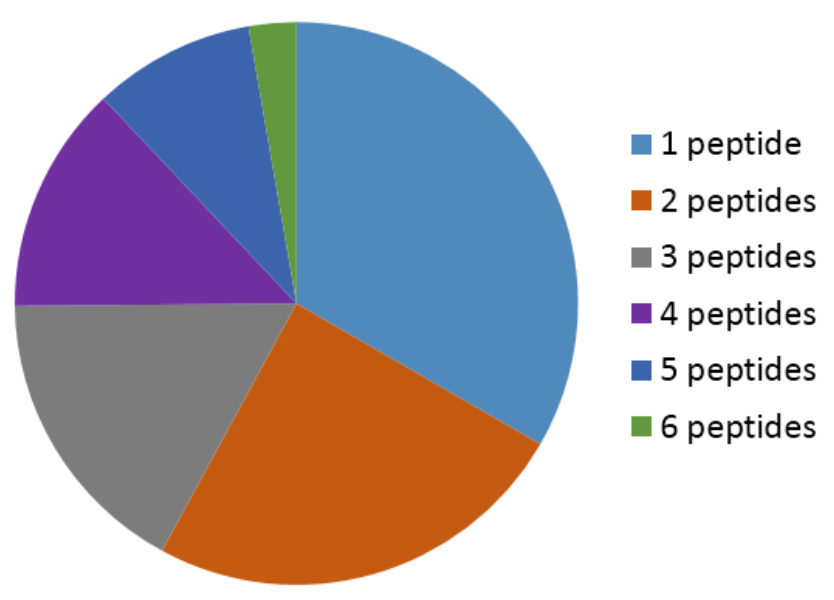

Figure 5. Reactivity of rheumatoid arthritis sera to linear citrullinated peptides. (a) Reactivity of 60 RA sera to five selected EBNA-1 peptides [136]; (b) Reactivity of 141 RA sera to six citrullinated peptides

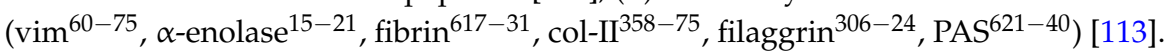


When conducting further experiments, we confirmed that ACPA responses are a group of antibodies with varying degrees of cross-reactivity. Analyzing antibody reactivity to multiple citrullinated peptides, among others, fibronectin, fibrinogen and filaggrin showed that multiple citrullinated peptides were recognized [131,133]. Screening of these patient sera using Ala-substituted peptides indicated that these peptides primarily were dependent on a central Cit-Gly motif, apparently in combination with a random peptide backbone [135]. Nevertheless, a small subgroup of patient sera was less cross-reactive, only recognizing a single or very few citrullinated peptides. Screening of these patient sera using alanine-substituted peptides indicated that the majority of the amino acids in the 14-mer pro-filaggrin peptide were essential for antibody reactivity (unpublished data). Thus, in this case, an actual epitope-specific ACPA response was identified, which is in great contrast to other studies indicating that ACPA reactivity is primarily dependent on the presence of a Cit-Gly motif $[79,131]$. Based on these results, we emphasize that "overlapping" cross-reactive ACPA reactivities primarily depend on a central Cit-Gly motif in combination with a flexible peptide backbone, whereas the "non-overlapping" non-cross-reactive ACPA reactivities depend on a citrullinated epitope, primarily being side chain-specific. However, this remains to be verified.

The polyclonal nature of ACPA responses in RA patients complicates the study of antibody characteristics such as cross-reactivity or affinity. What complicates the discussion about ACPAs even further is that in contrast to an antibody response to a specific protein, ACPAs are in fact a group of antibodies, each with its own citrullinated protein target. One way to circumvent these issues is to analyze the ACPA responses at a clonal level. Studies by us and van de Stadt et al. tested the reactivity of monoclonal antibodies to various citrullinated epitopes [80,133]. Analyzing the reactivity of these antibodies, significant reactivity was found to the target citrullinated protein, but distinct cross-reactivity was found towards citrullinated peptides derived from other proteins as well $[80,135]$. Moreover, findings by van de Stadt showed that the antibodies were derived from different naïve B cells that underwent extensive somatic hypermutation [80]. These results were further supported by recent studies, in which monoclonal antibodies generated against citrullinated collagen and fibrinogen, respectively, cross-reacted with other citrullinated antigens $[44,133]$. These findings are in accordance with studies performed by Ioan-Facsinay et al., where affinity-purified antibodies were able to recognize several citrullinated targets [143]. Thus, monoclonal and polyclonal antibody responses are similar in relation to ACPA reactivity, indicating that the identified ACPA reactivity pattern in human sera is the result of the presence of (partially) cross-reactive antibodies and not just the presence of co-existing mono-specificities.

\section{Conclusions}

The fact that ACPAs recognize multiple targets primarily containing essential Cit-Gly motifs has resulted in several studies analyzing ACPA reactivity to several citrullinated targets, as described in this review.

Collectively, ACPAs are a large collection of well-characterized, largely cross-reactive, but occasionally non-cross-reactive, fine specificities. However, the crucial importance of ACPA as a diagnostic marker and a potential contributor to the pathogenesis of RA has left limited room for thorough characterization of the actual antibody-antigen interface between ACPAs and their citrullinated targets. It is well described and accepted that ACPA reactivities primarily are of a cross-reactive nature; however, only limited knowledge is available in relation to the properties of the non-cross-reactive ACPAs. Studies indicate that the cross-reactive and non-cross-reactive ACPA responses in theory are two separate groups of antibodies. Other studies find that the cross-reactive ACPAs primarily depend on a central Cit-Gly motif in combination with the peptide backbone for reactivity. We suggest that non-cross-reactive ACPAs depend on a specific citrullinated epitope, rather than a citrullinated motif, thus making the fine specificities of the two groups of ACPAs different from each other. Focusing on the characterization of the non-cross-reactive antibody responses may 
reveal the true autoantigens of RA and contribute to understanding their nature, origin and potential function in the onset of RA.

Author Contributions: G.H. and N.H.T. contributed equally to the manuscript. G.H. and N.H.T. designed and wrote the manuscript.

Conflicts of Interest: The authors declare no conflict of interest.

\section{References}

1. Alamanos, Y.; Drosos, A.A. Epidemiology of adult rheumatoid arthritis. Autoimmun. Rev 2005, 4, 130-136. [CrossRef] [PubMed]

2. Girbal-Neuhauser, E.; Durieux, J.J.; Arnaud, M.; Dalbon, P.; Sebbag, M.; Vincent, C.; Simon, M.; Senshu, T.; Masson-Bessiere, C.; Jolivet-Reynaud, C.; et al. The epitopes targeted by the rheumatoid arthritis-associated antifilaggrin autoantibodies are posttranslationally generated on various sites of (pro)filaggrin by deimination of arginine residues. J Immunol. 1999, 162, 585-594. [PubMed]

3. Schellekens, G.A.; de Jong, B.A.; van den Hoogen, F.H.; van de Putte, L.B.; van Venrooij, W.J. Citrulline is an essential constituent of antigenic determinants recognized by rheumatoid arthritis-specific autoantibodies. J. Clin. Investig. 1998, 101, 273-281. [CrossRef] [PubMed]

4. Vossenaar, E.R.; Zendman, A.J.; van Venrooij, W.J.; Pruijn, G.J. PAD, a growing family of citrullinating enzymes: Genes, features and involvement in disease. Bioessays 2003, 25, 1106-1118. [CrossRef] [PubMed]

5. Guo, Q.; Bedford, M.T.; Fast, W. Discovery of peptidylarginine deiminase-4 substrates by protein array: Antagonistic citrullination and methylation of human ribosomal protein S2. Mol. Biosyst. 2011, 7, 2286-2295. [CrossRef] [PubMed]

6. Tarcsa, E.; Marekov, L.N.; Mei, G.; Melino, G.; Lee, S.C.; Steinert, P.M. Protein unfolding by peptidylarginine deiminase. Substrate specificity and structural relationships of the natural substrates trichohyalin and filaggrin. J. Biol. Chem. 1996, 271, 30709-30716. [CrossRef] [PubMed]

7. Gyorgy, B.; Toth, E.; Tarcsa, E.; Falus, A.; Buzas, E.I. Citrullination: A posttranslational modification in health and disease. Int. J. Biochem. Cell Biol. 2006, 38, 1662-1677. [CrossRef] [PubMed]

8. Inagaki, M.; Takahara, H.; Nishi, Y.; Sugawara, K.; Sato, C. Ca2+-dependent deimination-induced disassembly of intermediate filaments involves specific modification of the amino-terminal head domain. J. Biol. Chem. 1989, 264, 18119-18127. [PubMed]

9. Luban, S.; Li, Z.G. Citrullinated peptide and its relevance to rheumatoid arthritis: An update. Int. J. Rheum. Dis. 2010, 13, 284-287. [CrossRef] [PubMed]

10. Moeez, S.; John, P.; Bhatti, A. Anti-citrullinated protein antibodies: Role in pathogenesis of RA and potential as a diagnostic tool. Rheumatol. Int. 2013, 33, 1669-1673. [CrossRef] [PubMed]

11. Li, H.; Wan, A. Apoptosis of rheumatoid arthritis fibroblast-like synoviocytes: Possible roles of nitric oxide and the thioredoxin 1. Mediat. Inflamm. 2013, 2013, 953462. [CrossRef] [PubMed]

12. Suzuki, A.; Yamada, R.; Chang, X.; Tokuhiro, S.; Sawada, T.; Suzuki, M.; Nagasaki, M.; Nakayama-Hamada, M.; Kawaida, R.; Ono, M.; et al. Functional haplotypes of PADI4, encoding citrullinating enzyme peptidylarginine deiminase 4, are associated with rheumatoid arthritis. Nat. Genet. 2003, 34, 395-402. [CrossRef] [PubMed]

13. Vossenaar, E.R.; Radstake, T.R.; van der Heijden, A.; van Mansum, M.A.; Dieteren, C.; de Rooij, D.J.; Barrera, P.; Zendman, A.J.; van Venrooij, W.J. Expression and activity of citrullinating peptidylarginine deiminase enzymes in monocytes and macrophages. Ann. Rheum. Dis. 2004, 63, 373-381. [CrossRef] [PubMed]

14. Nielen, M.M.; van, S.D.; Reesink, H.W.; van de Stadt, R.J.; van der Horst-Bruinsma, I.E.; de Koning, M.H.; Habibuw, M.R.; Vandenbroucke, J.P.; Dijkmans, B.A. Specific autoantibodies precede the symptoms of rheumatoid arthritis: A study of serial measurements in blood donors. Arthritis Rheum. 2004, 50, 380-386. [CrossRef] [PubMed]

15. Rantapaa-Dahlqvist, S.; de Jong, B.A.; Berglin, E.; Hallmans, G.; Wadell, G.; Stenlund, H.; Sundin, U.; van Venrooij, W.J. Antibodies against cyclic citrullinated peptide and IgA rheumatoid factor predict the development of rheumatoid arthritis. Arthritis Rheum. 2003, 48, 2741-2749. [CrossRef] [PubMed]

16. Ling, S.; Pi, X.; Holoshitz, J. The rheumatoid arthritis shared epitope triggers innate immune signaling via cell surface calreticulin. J. Immunol. 2007, 179, 6359-6367. [CrossRef] [PubMed] 
17. Ling, S.; Cheng, A.; Pumpens, P.; Michalak, M.; Holoshitz, J. Identification of the rheumatoid arthritis shared epitope binding site on calreticulin. PLoS ONE 2010, 5, e11703. [CrossRef] [PubMed]

18. Ling, S.; Cline, E.N.; Haug, T.S.; Fox, D.A.; Holoshitz, J. Citrullinated calreticulin potentiates rheumatoid arthritis shared epitope signaling. Arthritis Rheum. 2013, 65, 618-626. [CrossRef] [PubMed]

19. Holoshitz, J.; de Almeida, D.E.; Ling, S. A role for calreticulin in the pathogenesis of rheumatoid arthritis. Ann. N. Y. Acad. Sci. 2010, 1209, 91-98. [CrossRef] [PubMed]

20. Esposito, G.; Vitale, A.M.; Leijten, F.P.; Strik, A.M.; Koonen-Reemst, A.M.; Yurttas, P.; Robben, T.J.; Coonrod, S.; Gossen, J.A. Peptidylarginine deiminase (PAD) 6 is essential for oocyte cytoskeletal sheet formation and female fertility. Mol. Cell. Endocrinol. 2007, 273, 25-31. [CrossRef] [PubMed]

21. Pritzker, L.B.; Nguyen, T.A.; Moscarello, M.A. The developmental expression and activity of peptidylarginine deiminase in the mouse. Neurosci. Lett. 1999, 266, 161-164. [CrossRef]

22. Rogers, G.; Winter, B.; McLaughlan, C.; Powell, B.; Nesci, T. Peptidylarginine deiminase of the hair follicle: Characterization, localization, and function in keratinizing tissues. J. Investig. Dermatol. 1997, 108, 700-707. [CrossRef] [PubMed]

23. Nakashima, K.; Hagiwara, T.; Yamada, M. Nuclear localization of peptidylarginine deiminase V and histone deimination in granulocytes. J. Biol. Chem. 2002, 277, 49562-49568. [CrossRef] [PubMed]

24. Denis, H.; Deplus, R.; Putmans, P.; Yamada, M.; Metivier, R.; Fuks, F. Functional connection between deimination and deacetylation of histones. Mol. Cell. Biol. 2009, 29, 4982-4993. [CrossRef] [PubMed]

25. Dong, S.; Zhang, Z.; Takahara, H. Estrogen-enhanced peptidylarginine deiminase type IV gene (PADI4) expression in MCF-7 cells is mediated by estrogen receptor-alpha-promoted transfactors activator protein-1, nuclear factor-Y, and Sp1. Mol. Endocrinol. 2007, 21, 1617-1629. [CrossRef] [PubMed]

26. Guo, Q.; Fast, W. Citrullination of inhibitor of growth 4 (ING4) by peptidylarginine deminase 4 (PAD4) disrupts the interaction between ING4 and p53. J. Biol. Chem. 2011, 286, 17069-17078. [CrossRef] [PubMed]

27. Li, P.; Yao, H.; Zhang, Z.; Li, M.; Luo, Y.; Thompson, P.R.; Gilmour, D.S.; Wang, Y. Regulation of p53 target gene expression by peptidylarginine deiminase 4. Mol. Cell. Biol. 2008, 28, 4745-4758. [CrossRef] [PubMed]

28. Liu, G.Y.; Liao, Y.F.; Chang, W.H.; Liu, C.C.; Hsieh, M.C.; Hsu, P.C.; Tsay, G.J.; Hung, H.C. Overexpression of peptidylarginine deiminase IV features in apoptosis of haematopoietic cells. Apoptosis 2006, 11, 183-196. [CrossRef] [PubMed]

29. Tanikawa, C.; Ueda, K.; Nakagawa, H.; Yoshida, N.; Nakamura, Y.; Matsuda, K. Regulation of protein Citrullination through p53/PADI4 network in DNA damage response. Cancer Res. 2009, 69, 8761-8769. [CrossRef] [PubMed]

30. Yao, H.; Li, P.; Venters, B.J.; Zheng, S.; Thompson, P.R.; Pugh, B.F.; Wang, Y. Histone Arg modifications and p53 regulate the expression of OKL38, a mediator of apoptosis. J. Biol. Chem. 2008, 283, 20060-20068. [CrossRef] [PubMed]

31. Lee, H.J.; Joo, M.; Abdolrasulnia, R.; Young, D.G.; Choi, I.; Ware, L.B.; Blackwell, T.S.; Christman, B.W. Peptidylarginine deiminase 2 suppresses inhibitory \{kappa\}B kinase activity in lipopolysaccharide-stimulated RAW 264.7 macrophages. J. Biol. Chem. 2010, 285, 39655-39662. [CrossRef] [PubMed]

32. Li, P.; Li, M.; Lindberg, M.R.; Kennett, M.J.; Xiong, N.; Wang, Y. PAD4 is essential for antibacterial innate immunity mediated by neutrophil extracellular traps. J. Exp. Med. 2010, 207, 1853-1862. [CrossRef] [PubMed]

33. Loos, T.; Mortier, A.; Gouwy, M.; Ronsse, I.; Put, W.; Lenaerts, J.P.; van Damme, J.; Proost, P. Citrullination of CXCL10 and CXCL11 by peptidylarginine deiminase: A naturally occurring posttranslational modification of chemokines and new dimension of immunoregulation. Blood 2008, 112, 2648-2656. [CrossRef] [PubMed]

34. Loos, T.; Opdenakker, G.; van Damme, J.; Proost, P. Citrullination of CXCL8 increases this chemokine's ability to mobilize neutrophils into the blood circulation. Haematologica 2009, 94, 1346-1353. [CrossRef] [PubMed]

35. Mastronardi, F.G.; Wood, D.D.; Mei, J.; Raijmakers, R.; Tseveleki, V.; Dosch, H.M.; Probert, L.; Casaccia-Bonnefil, P.; Moscarello, M.A. Increased citrullination of histone $\mathrm{H} 3$ in multiple sclerosis brain and animal models of demyelination: A role for tumor necrosis factor-induced peptidylarginine deiminase 4 translocation. J. Neurosci. 2006, 26, 11387-11396. [CrossRef] [PubMed]

36. Proost, P.; Loos, T.; Mortier, A.; Schutyser, E.; Gouwy, M.; Noppen, S.; Dillen, C.; Ronsse, I.; Conings, R.; Struyf, S.; et al. Citrullination of CXCL8 by peptidylarginine deiminase alters receptor usage, prevents proteolysis, and dampens tissue inflammation. J. Exp. Med. 2008, 205, 2085-2097. [CrossRef] [PubMed] 
37. Rohrbach, A.S.; Slade, D.J.; Thompson, P.R.; Mowen, K.A. Activation of PAD4 in NET formation. Front. Immunol. 2012, 3, 360. [CrossRef] [PubMed]

38. Klareskog, L.; Ronnelid, J.; Lundberg, K.; Padyukov, L.; Alfredsson, L. Immunity to citrullinated proteins in rheumatoid arthritis. Annu. Rev. Immunol. 2008, 26, 651-675. [CrossRef] [PubMed]

39. Payet, J.; Goulvestre, C.; Biale, L.; Avouac, J.; Wipff, J.; Job-Deslandre, C.; Batteux, F.; Dougados, M.; Kahan, A.; Allanore, Y. Anticyclic citrullinated peptide antibodies in rheumatoid and nonrheumatoid rheumatic disorders: Experience with 1162 patients. J. Rheumatol. 2014, 41, 2395-2402. [CrossRef] [PubMed]

40. Vossenaar, E.R.; Smeets, T.J.; Kraan, M.C.; Raats, J.M.; van Venrooij, W.J.; Tak, P.P. The presence of citrullinated proteins is not specific for rheumatoid synovial tissue. Arthritis Rheum. 2004, 50, 3485-3494. [CrossRef] [PubMed]

41. Vincent, C.; Nogueira, L.; Clavel, C.; Sebbag, M.; Serre, G. Autoantibodies to citrullinated proteins: ACPA. Autoimmunity 2005, 38, 17-24. [CrossRef] [PubMed]

42. Baeten, D.; Peene, I.; Union, A.; Meheus, L.; Sebbag, M.; Serre, G.; Veys, E.M.; de Keyser, F. Specific presence of intracellular citrullinated proteins in rheumatoid arthritis synovium: Relevance to antifilaggrin autoantibodies. Arthritis Rheum. 2001, 44, 2255-2262. [CrossRef]

43. Snir, O.; Widhe, M.; Hermansson, M.; von, S.C.; Lindberg, J.; Hensen, S.; Lundberg, K.; Engstrom, A.; Venables, P.J.; Toes, R.E.; et al. Antibodies to several citrullinated antigens are enriched in the joints of rheumatoid arthritis patients. Arthritis Rheum. 2010, 62, 44-52. [CrossRef] [PubMed]

44. Uysal, H.; Bockermann, R.; Nandakumar, K.S.; Sehnert, B.; Bajtner, E.; Engstrom, A.; Serre, G.; Burkhardt, H.; Thunnissen, M.M.; Holmdahl, R. Structure and pathogenicity of antibodies specific for citrullinated collagen type II in experimental arthritis. J. Exp. Med. 2009, 206, 449-462. [CrossRef] [PubMed]

45. Reynisdottir, G.; Karimi, R.; Joshua, V.; Olsen, H.; Hensvold, A.H.; Harju, A.; Engstrom, M.; Grunewald, J.; Nyren, S.; Eklund, A.; et al. Structural changes and antibody enrichment in the lungs are early features of anti-citrullinated protein antibody-positive rheumatoid arthritis. Arthritis Rheumatol. 2014, 66, 31-39. [CrossRef] [PubMed]

46. Anzilotti, C.; Riente, L.; Pratesi, F.; Chimenti, D.; Delle, S.A.; Bombardieri, S.; Migliorini, P. IgG, IgA, IgM antibodies to a viral citrullinated peptide in patients affected by rheumatoid arthritis, chronic arthritides and connective tissue disorders. Rheumatology (Oxford) 2007, 46, 1579-1582. [CrossRef] [PubMed]

47. Ioan-Facsinay, A.; Willemze, A.; Robinson, D.B.; Peschken, C.A.; Markland, J.; van der Woude, D.; Elias, B.; Menard, H.A.; Newkirk, M.; Fritzler, M.J.; et al. Marked differences in fine specificity and isotype usage of the anti-citrullinated protein antibody in health and disease. Arthritis Rheum. 2008, 58, 3000-3008. [CrossRef] [PubMed]

48. Suwannalai, P.; Willemze, A.; van, T.L.; Stoeken-Rijsbergen, G.; Levarht, N.; Drijfhout, J.W.; Huizinga, T.W.; Toes, R.E.; Trouw, L.A. The fine specificity of IgM anti-citrullinated protein antibodies (ACPA) is different from that of IgG ACPA. Arthritis Res. Ther. 2011, 13, R195. [CrossRef] [PubMed]

49. Humphreys, J.H.; van Nies, J.A.; Chipping, J.; Marshall, T.; van der Helm-van Mil, A.H.; Symmons, D.P.; Verstappen, S.M. Rheumatoid factor and anti-citrullinated protein antibody positivity, but not level, are associated with increased mortality in patients with rheumatoid arthritis: Results from two large independent cohorts. Arthritis Res. Ther. 2014, 16, 483. [PubMed]

50. Quinn, M.A.; Gough, A.K.; Green, M.J.; Devlin, J.; Hensor, E.M.; Greenstein, A.; Fraser, A.; Emery, P. Anti-CCP antibodies measured at disease onset help identify seronegative rheumatoid arthritis and predict radiological and functional outcome. Rheumatology (Oxford) 2006, 45, 478-480. [CrossRef] [PubMed]

51. Ronnelid, J.; Wick, M.C.; Lampa, J.; Lindblad, S.; Nordmark, B.; Klareskog, L.; van Vollenhoven, R.F. Longitudinal analysis of citrullinated protein/peptide antibodies (anti-CP) during 5 year follow up in early rheumatoid arthritis: Anti-CP status predicts worse disease activity and greater radiological progression. Ann. Rheum. Dis. 2005, 64, 1744-1749. [CrossRef] [PubMed]

52. Van Gaalen, F.A.; Linn-Rasker, S.P.; van Venrooij, W.J.; de Jong, B.A.; Breedveld, F.C.; Verweij, C.L.; Toes, R.E.; Huizinga, T.W. Autoantibodies to cyclic citrullinated peptides predict progression to rheumatoid arthritis in patients with undifferentiated arthritis: A prospective cohort study. Arthritis Rheum. 2004, 50, 709-715. [CrossRef] [PubMed]

53. Nielen, M.M.; van der Horst, A.R.; van, S.D.; van der Horst-Bruinsma, I.E.; van de Stadt, R.J.; Aarden, L.; Dijkmans, B.A.; Hamann, D. Antibodies to citrullinated human fibrinogen (ACF) have diagnostic and prognostic value in early arthritis. Ann. Rheum. Dis. 2005, 64, 1199-1204. [CrossRef] [PubMed] 
54. Van der Helm-van Mil, A.H.; Verpoort, K.N.; Breedveld, F.C.; Toes, R.E.; Huizinga, T.W. Antibodies to citrullinated proteins and differences in clinical progression of rheumatoid arthritis. Arthritis Res. Ther. 2005, 7, R949-R958. [CrossRef] [PubMed]

55. Szekanecz, Z.; Soos, L.; Szabo, Z.; Fekete, A.; Kapitany, A.; Vegvari, A.; Sipka, S.; Szucs, G.; Szanto, S.; Lakos, G. Anti-citrullinated protein antibodies in rheumatoid arthritis: As good as it gets? Clin. Rev. Allergy Immunol. 2008, 34, 26-31. [CrossRef] [PubMed]

56. Nienhuis, R.L.; Mandema, E. A new serum factor in patients with rheumatoid arthritis; the antiperinuclear factor. Ann. Rheum. Dis. 1964, 23, 302-305. [CrossRef] [PubMed]

57. Young, B.J.; Mallya, R.K.; Leslie, R.D.; Clark, C.J.; Hamblin, T.J. Anti-keratin antibodies in rheumatoid arthritis. Br. Med. J. 1979, 2, 97-99. [CrossRef] [PubMed]

58. Sebbag, M.; Simon, M.; Vincent, C.; Masson-Bessiere, C.; Girbal, E.; Durieux, J.J.; Serre, G. The antiperinuclear factor and the so-called antikeratin antibodies are the same rheumatoid arthritis-specific autoantibodies. J. Clin. Investig. 1995, 95, 2672-2679. [CrossRef] [PubMed]

59. Simon, M.; Girbal, E.; Sebbag, M.; Gomes-Daudrix, V.; Vincent, C.; Salama, G.; Serre, G. The cytokeratin filament-aggregating protein filaggrin is the target of the so-called "antikeratin antibodies", autoantibodies specific for rheumatoid arthritis. J. Clin. Investig. 1993, 92, 1387-1393. [CrossRef] [PubMed]

60. Simon, M.; Vincent, C.; Haftek, M.; Girbal, E.; Sebbag, M.; Gomes-Daudrix, V.; Serre, G. The rheumatoid arthritis-associated autoantibodies to filaggrin label the fibrous matrix of the cornified cells but not the profilaggrin-containing keratohyalin granules in human epidermis. Clin. Exp. Immunol. 1995, 100, 90-98. [CrossRef] [PubMed]

61. Despres, N.; Boire, G.; Lopez-Longo, F.J.; Menard, H.A. The Sa system: A novel antigen-antibody system specific for rheumatoid arthritis. J. Rheumatol. 1994, 21, 1027-1033. [PubMed]

62. Hayem, G.; Chazerain, P.; Combe, B.; Elias, A.; Haim, T.; Nicaise, P.; Benali, K.; Eliaou, J.F.; Kahn, M.F.; Sany, J.; et al. Anti-Sa antibody is an accurate diagnostic and prognostic marker in adult rheumatoid arthritis. J. Rheumatol. 1999, 26, 7-13. [PubMed]

63. Bang, H.; Egerer, K.; Gauliard, A.; Luthke, K.; Rudolph, P.E.; Fredenhagen, G.; Berg, W.; Feist, E.; Burmester, G.R. Mutation and citrullination modifies vimentin to a novel autoantigen for rheumatoid arthritis. Arthritis Rheum. 2007, 56, 2503-2511. [CrossRef] [PubMed]

64. Schellekens, G.A.; Visser, H.; de Jong, B.A.; van den Hoogen, F.H.; Hazes, J.M.; Breedveld, F.C.; van Venrooij, W.J. The diagnostic properties of rheumatoid arthritis antibodies recognizing a cyclic citrullinated peptide. Arthritis Rheum. 2000, 43, 155-163. [CrossRef]

65. Aggarwal, R.; Liao, K.; Nair, R.; Ringold, S.; Costenbader, K.H. Anti-citrullinated peptide antibody assays and their role in the diagnosis of rheumatoid arthritis. Arthritis Rheum. 2009, 61, 1472-1483. [CrossRef] [PubMed]

66. Coenen, D.; Verschueren, P.; Westhovens, R.; Bossuyt, X. Technical and diagnostic performance of 6 assays for the measurement of citrullinated protein/peptide antibodies in the diagnosis of rheumatoid arthritis. Clin. Chem. 2007, 53, 498-504. [CrossRef] [PubMed]

67. Correia, M.L.; Carvalho, S.; Fortuna, J.; Pereira, M.H. Comparison of three anti-CCP antibody tests and rheumatoid factor in RA and control patients. Clin. Rev. Allergy Immunol. 2008, 34, 21-25. [CrossRef] [PubMed]

68. Santiago, M.; Baron, M.; Miyachi, K.; Fritzler, M.J.; Abu-Hakima, M.; Leclercq, S.; Bell, M.; Hudson, M.; Mathieu, J.P.; Taillefer, S.; et al. A comparison of the frequency of antibodies to cyclic citrullinated peptides using a third generation anti-CCP assay (CCP3) in systemic sclerosis, primary biliary cirrhosis and rheumatoid arthritis. Clin. Rheumatol. 2008, 27, 77-83. [CrossRef] [PubMed]

69. Hoet, R.M.; Boerbooms, A.M.; Arends, M.; Ruiter, D.J.; van Venrooij, W.J. Antiperinuclear factor, a marker autoantibody for rheumatoid arthritis: Colocalisation of the perinuclear factor and profilaggrin. Ann. Rheum. Dis. 1991, 50, 611-618. [CrossRef] [PubMed]

70. Steiner, G.; Smolen, J. Autoantibodies in rheumatoid arthritis and their clinical significance. Arthritis Res. 2002, 4, S1-S5. [CrossRef] [PubMed]

71. Van Boekel, M.A.; Vossenaar, E.R.; van den Hoogen, F.H.; van Venrooij, W.J. Autoantibody systems in rheumatoid arthritis: Specificity, sensitivity and diagnostic value. Arthritis Res. 2002, 4, 87-93. [CrossRef] [PubMed] 
72. Masson-Bessiere, C.; Sebbag, M.; Girbal-Neuhauser, E.; Nogueira, L.; Vincent, C.; Senshu, T.; Serre, G. The major synovial targets of the rheumatoid arthritis-specific antifilaggrin autoantibodies are deiminated forms of the alpha- and beta-chains of fibrin. J. Immunol. 2001, 166, 4177-4184. [CrossRef] [PubMed]

73. Iobagiu, C.; Magyar, A.; Nogueira, L.; Cornillet, M.; Sebbag, M.; Arnaud, J.; Hudecz, F.; Serre, G. The antigen specificity of the rheumatoid arthritis-associated ACPA directed to citrullinated fibrin is very closely restricted. J. Autoimmun. 2011, 37, 263-272. [CrossRef] [PubMed]

74. Nishimura, K.; Sugiyama, D.; Kogata, Y.; Tsuji, G.; Nakazawa, T.; Kawano, S.; Saigo, K.; Morinobu, A.; Koshiba, M.; Kuntz, K.M.; et al. Meta-analysis: Diagnostic accuracy of anti-cyclic citrullinated peptide antibody and rheumatoid factor for rheumatoid arthritis. Ann. Intern. Med. 2007, 146, 797-808. [CrossRef] [PubMed]

75. Szekanecz, Z.; Szabo, Z.; Zeher, M.; Soos, L.; Danko, K.; Horvath, I.; Lakos, G. Superior performance of the CCP3.1 test compared to CCP2 and MCV in the rheumatoid factor-negative RA population. Immunol. Res. 2013, 56, 439-443. [CrossRef] [PubMed]

76. Bizzaro, N.; Tonutti, E.; Tozzoli, R.; Villalta, D. Analytical and diagnostic characteristics of 11 2ndand 3rd-generation immunoenzymatic methods for the detection of antibodies to citrullinated proteins. Clin. Chem. 2007, 53, 1527-1533. [CrossRef] [PubMed]

77. Lopez-Longo, F.J.; Rodriguez-Mahou, M.; Sanchez-Ramon, S.; Estecha, A.; Balsera, M.; Plaza, R.; Fernandez-Cruz, E.; Perez, L.C. Anti-cyclic citrullinated peptide versus anti-Sa antibodies in diagnosis of rheumatoid arthritis in an outpatient clinic for connective tissue disease and spondyloarthritis. J. Rheumatol. 2006, 33, 1476-1481. [PubMed]

78. Wagner, E.; Skoumal, M.; Bayer, P.M.; Klaushofer, K. Antibody against mutated citrullinated vimentin: A new sensitive marker in the diagnosis of rheumatoid arthritis. Rheumatol. Int. 2009, 29, 1315-1321. [CrossRef] [PubMed]

79. Trier, N.H.; Holm, B.E.; Slot, O.; Locht, H.; Lindegaard, H.; Svendsen, A.; Nielsen, C.T.; Jacobsen, S.; Theander, E.; Houen, G. Application of synthetic peptides for detection of anti-citrullinated peptide antibodies. Peptides 2016, 76, 87-95. [CrossRef] [PubMed]

80. Van de Stadt, L.A.; de Koning, M.H.; van de Stadt, R.J.; Wolbink, G.; Dijkmans, B.A.; Hamann, D.; van Schaardenburg, D. Development of the anti-citrullinated protein antibody repertoire prior to the onset of rheumatoid arthritis. Arthritis Rheum. 2011, 63, 3226-3233. [CrossRef] [PubMed]

81. Van Venrooij, W.J.; van Beers, J.J.; Pruijn, G.J. Anti-CCP Antibody, a Marker for the Early Detection of Rheumatoid Arthritis. Ann. N. Y. Acad. Sci. 2008, 1143, 268-285. [CrossRef] [PubMed]

82. Aletaha, D.; Neogi, T.; Silman, A.J.; Funovits, J.; Felson, D.T.; Bingham, C.O.; Birnbaum, N.S.; Burmester, G.R.; Bykerk, V.P.; Cohen, M.D.; et al. 2010 Rheumatoid arthritis classification criteria: An American College of Rheumatology/European League Against Rheumatism collaborative initiative. Arthritis Rheum. 2010, 62, 2569-2581. [CrossRef] [PubMed]

83. Arnett, F.C.; Edworthy, S.M.; Bloch, D.A.; McShane, D.J.; Fries, J.F.; Cooper, N.S.; Healey, L.A.; Kaplan, S.R.; Liang, M.H.; Luthra, H.S. The American Rheumatism Association 1987 revised criteria for the classification of rheumatoid arthritis. Arthritis Rheum. 1988, 31, 315-324. [CrossRef] [PubMed]

84. Fernandes-Cerqueira, C.; Ossipova, E.; Gunasekera, S.; Hansson, M.; Mathsson, L.; Catrina, A.I.; Sommarin, Y.; Klareskog, L.; Lundberg, K.; Ronnelid, J.; et al. Targeting of anti-citrullinated protein/peptide antibodies in rheumatoid arthritis using peptides mimicking endogenously citrullinated fibrinogen antigens. Arthritis Res. Ther. 2015, 17, 155. [CrossRef] [PubMed]

85. Lundberg, K.; Bengtsson, C.; Kharlamova, N.; Reed, E.; Jiang, X.; Kallberg, H.; Pollak-Dorocic, I.; Israelsson, L.; Kessel, C.; Padyukov, L.; et al. Genetic and environmental determinants for disease risk in subsets of rheumatoid arthritis defined by the anticitrullinated protein/peptide antibody fine specificity profile. Ann. Rheum. Dis. 2013, 72, 652-658. [CrossRef] [PubMed]

86. Wagner, C.A.; Sokolove, J.; Lahey, L.J.; Bengtsson, C.; Saevarsdottir, S.; Alfredsson, L.; Delanoy, M.; Lindstrom, T.M.; Walker, R.P.; Bromberg, R.; et al. Identification of anticitrullinated protein antibody reactivities in a subset of anti-CCP-negative rheumatoid arthritis: Association with cigarette smoking and HLA-DRB1 'shared epitope' alleles. Ann. Rheum. Dis. 2015, 74, 579-586. [CrossRef] [PubMed]

87. Okamoto, H.; Kobayashi, A. Tyrosine kinases in rheumatoid arthritis. J. Inflamm. (London) $2011,8,21$. [CrossRef] [PubMed] 
88. Cohen, S.B.; Emery, P.; Greenwald, M.W.; Dougados, M.; Furie, R.A.; Genovese, M.C.; Keystone, E.C.; Loveless, J.E.; Burmester, G.R.; Cravets, M.W.; et al. Rituximab for rheumatoid arthritis refractory to anti-tumor necrosis factor therapy: Results of a multicenter, randomized, double-blind, placebo-controlled, phase III trial evaluating primary efficacy and safety at twenty-four weeks. Arthritis Rheum. 2006, 54, 2793-2806. [CrossRef] [PubMed]

89. Edwards, J.C.; Szczepanski, L.; Szechinski, J.; Filipowicz-Sosnowska, A.; Emery, P.; Close, D.R.; Stevens, R.M.; Shaw, T. Efficacy of B-cell-targeted therapy with rituximab in patients with rheumatoid arthritis. N. Engl. J. Med. 2004, 350, 2572-2581. [CrossRef] [PubMed]

90. Kuhn, K.A.; Kulik, L.; Tomooka, B.; Braschler, K.J.; Arend, W.P.; Robinson, W.H.; Holers, V.M. Antibodies against citrullinated proteins enhance tissue injury in experimental autoimmune arthritis. J. Clin. Investig. 2006, 116, 961-973. [CrossRef] [PubMed]

91. Clavel, C.; Nogueira, L.; Laurent, L.; Iobagiu, C.; Vincent, C.; Sebbag, M.; Serre, G. Induction of macrophage secretion of tumor necrosis factor alpha through Fcgamma receptor IIa engagement by rheumatoid arthritis-specific autoantibodies to citrullinated proteins complexed with fibrinogen. Arthritis Rheum. 2008, 58, 678-688. [CrossRef] [PubMed]

92. Trouw, L.A.; Haisma, E.M.; Levarht, E.W.; van der Woude, D.; Ioan-Facsinay, A.; Daha, M.R.; Huizinga, T.W.; Toes, R.E. Anti-cyclic citrullinated peptide antibodies from rheumatoid arthritis patients activate complement via both the classical and alternative pathways. Arthritis Rheum. 2009, 60, 1923-1931. [CrossRef] [PubMed]

93. Cheng, Y.; Yang, F.; Huang, C.; Huang, J.; Wang, Q.; Chen, Y.; Du, Y.; Zhao, L.; Gao, M.; Wang, F. Plasmapheresis Therapy in Combination with TNF-alpha Inhibitor and DMARDs: A Multi-Target Method for Treatment of Rheumatoid Arthritis. Mod. Rheumatol. 2016, 1-17. [CrossRef] [PubMed]

94. Fabris, M.; de Vita, S.; Blasone, N.; Visentini, D.; Pezzarini, E.; Pontarini, E.; Fabro, C.; Quartuccio, L.; Mazzolini, S.; Curcio, F.; et al. Serum levels of anti-CCP antibodies, anti-MCV antibodies and RF IgA in the follow-up of patients with rheumatoid arthritis treated with rituximab. Autoimmun. Highlights 2010, 1, 87-94. [CrossRef] [PubMed]

95. Van Steendam, K.; Tilleman, K.; de Ceuleneer, M.; de Keyser, F.; Elewaut, D.; Deforce, D. Citrullinated vimentin as an important antigen in immune complexes from synovial fluid of rheumatoid arthritis patients with antibodies against citrullinated proteins. Arthritis Res. Ther. 2010, 12, R132. [CrossRef] [PubMed]

96. James, E.A.; Rieck, M.; Pieper, J.; Gebe, J.A.; Yue, B.B.; Tatum, M.; Peda, M.; Sandin, C.; Klareskog, L.; Malmstrom, V.; et al. Citrulline-specific Th1 cells are increased in rheumatoid arthritis and their frequency is influenced by disease duration and therapy. Arthritis Rheumatol. 2014, 66, 1712-1722. [CrossRef] [PubMed]

97. Klarenbeek, P.L.; de Hair, M.J.; Doorensplet, M.E.; van Schaik, B.D.; Esveldt, R.E.; van de Sande, M.G.; Cantaert, T.; Gerlag, D.M.; Bae Baeten, D.; van Kampen, A.H.; et al. Inflamed target tissue provides a specific niche for highly expanded T-cell clones in early human autoimmune disease. Ann. Rheum. Dis. 2012, 71 , 1088-1093. [CrossRef] [PubMed]

98. Cantaert, T.; Brouard, S.; Thurlings, R.M.; Pallier, A.; Salinas, G.F.; Braud, C.; Klarenbeek, P.L.; de Vries, N.; Zhang, Y.; Soulillou, J.P.; et al. Alterations of the synovial T cell repertoire in anticitrullinated protein antibody-positive rheumatoid arthritis. Ahtritis Rheum. 2009, 60, 1944-1956. [CrossRef] [PubMed]

99. Hill, J.A.; Southwood, S.; Sette, A.; Jevnikar, A.M.; Bell, D.A.; Cairns, E. Cutting edge: The conversion of arginine to citrulline allows for a high-affinity peptide interaction with the rheumatoid arthritis-associated HLA-DRB1*0401 MHC class II molecule. J. Immunol. 2003, 171, 538-541. [CrossRef] [PubMed]

100. Hill, J.A.; Wang, D.; Jevnikar, A.M.; Cairns, E.; Bell, D.A. The relationship between predicted peptide-MHC class II affinity and T-cell activation in a HLA-DRbeta1*0401 transgenic mouse model. Arthritis Res. Ther. 2003, 5, R40-R48. [CrossRef] [PubMed]

101. James, E.A.; Moustakas, A.K.; Bui, J.; Papadopoulos, G.K.; Bondinas, G.; Buckner, J.H.; Kwok, W.W. HLA-DR1001 presents "altered-self" peptides derived from joint-associated proteins by accepting citrulline in three of its binding pockets. Arthritis Rheum. 2010, 62, 2909-2918. [CrossRef] [PubMed]

102. Law, S.C.; Street, S.; Yu, C.H.; Capini, C.; Ramnoruth, S.; Nel, H.J.; van Gorp, E.; Hyde, C.; Lau, K.; Pahau, H.; et al. T-cell autoreactivity to citrullinated autoantigenic peptides in rheumatoid arthritis patients carrying HLA-DRB1 shared epitope alleles. Arthritis Res Ther. 2012, 14, R118. [CrossRef] [PubMed]

103. Snir, O.; Rieck, M.; Gebe, J.A.; Yue, B.B.; Rawlings, C.A.; Nepom, G.; Malmstrom, V.; Buckner, J.H. Identification and functional characterization of $\mathrm{T}$ cells reactive to citrullinated vimentin in HLA-DRB1*0401-positive humanized mice and rheumatoid arthritis patients. Arthritis Rheum. 2011, 63, 2873-2883. [CrossRef] [PubMed] 
104. Chemin, K.; Pollastro, S.; James, E.; Ge, C.; Albrecht, I.; Herrath, J.; Gerstner, C.; Tandre, K.; Sampaio Rizzi, T.; Rönnblom, L.; et al. A novel HLA-DRB1*10:01 restricted T cell epitope from cirullinated type II collagen relevant for rheumatoid ahtritis. Arthritis Rheum. 2016, 68, 1124-1125.

105. Feitsma, A.L.; van der Voort, E.I.; Franken, K.L.; el Bannoudi, H.; Elferink, B.G.; Drijfhout, J.W.; Huizinga, T.W.; de Vries, R.R.; Toes, R.E.; Ioan-Facsinay, A. Identification of citrullinated vimentin peptides as T cell epitopes in HLA-DR4-positive patients with rheumatoid arthritis. Arthritis Rheum. 2010, 62, 117-125. [CrossRef] [PubMed]

106. MacGregor, A.J.; Snieder, H.; Rigby, A.S.; Koskenvuo, M.; Kaprio, J.; Aho, K.; Silman, A.J. Characterizing the quantitative genetic contribution to rheumatoid arthritis using data from twins. Arthritis Rheum. 2000, 43, 30-37. [CrossRef]

107. Scott, D.L.; Wolfe, F.; Huizinga, T.W. Rheumatoid arthritis. Lancet 2010, 376, 1094-1108. [CrossRef]

108. Stastny, P. Mixed lymphocyte cultures in rheumatoid arthritis. J. Clin. Investig. 1976, 57, 1148-1157. [CrossRef] [PubMed]

109. Holoshitz, J. The rheumatoid arthritis HLA-DRB1 shared epitope. Curr. Opin. Rheumatol. 2010, 22, $293-298$. [CrossRef] [PubMed]

110. Bhayani, H.R.; Hedrick, S.M. The role of polymorphic amino acids of the MHC molecule in the selection of the T cell repertoire. J. Immunol. 1991, 146, 1093-1098. [PubMed]

111. Wucherpfennig, K.W.; Strominger, J.L. Selective binding of self peptides to disease-associated major histocompatibility complex (MHC) molecules: A mechanism for MHC-linked susceptibility to human autoimmune diseases. J. Exp. Med. 1995, 181, 1597-1601. [CrossRef] [PubMed]

112. Kapitany, A.; Szabo, Z.; Lakos, G.; Aleksza, M.; Vegvari, A.; Soos, L.; Karanyi, Z.; Sipka, S.; Szegedi, G.; Szekanecz, Z. Associations between serum anti-CCP antibody, rheumatoid factor levels and HLA-DR4 expression in Hungarian patients with rheumatoid arthritis. Isr. Med. Assoc. J. 2008, 10, 32-36. [PubMed]

113. Snir, O.; Widhe, M.; von, S.C.; Lindberg, J.; Padyukov, L.; Lundberg, K.; Engstrom, A.; Venables, P.J.; Lundeberg, J.; Holmdahl, R.; et al. Multiple antibody reactivities to citrullinated antigens in sera from patients with rheumatoid arthritis: Association with HLA-DRB1 alleles. Ann. Rheum. Dis. 2009, 68, 736-743. [CrossRef] [PubMed]

114. Begovich, A.B.; Carlton, V.E.; Honigberg, L.A.; Schrodi, S.J.; Chokkalingam, A.P.; Alexander, H.C.; Ardlie, K.G.; Huang, Q.; Smith, A.M.; Spoerke, J.M.; et al. A missense single-nucleotide polymorphism in a gene encoding a protein tyrosine phosphatase (PTPN22) is associated with rheumatoid arthritis. Am. J. Hum. Genet. 2004, 75, 330-337. [CrossRef] [PubMed]

115. Plenge, R.M.; Padyukov, L.; Remmers, E.F.; Purcell, S.; Lee, A.T.; Karlson, E.W.; Wolfe, F.; Kastner, D.L.; Alfredsson, L.; Altshuler, D.; et al. Replication of putative candidate-gene associations with rheumatoid arthritis in >4,000 samples from North America and Sweden: Association of susceptibility with PTPN22, CTLA4, and PADI4. Am. J. Hum. Genet. 2005, 77, 1044-1060. [CrossRef] [PubMed]

116. Klareskog, L.; Stolt, P.; Lundberg, K.; Kallberg, H.; Bengtsson, C.; Grunewald, J.; Ronnelid, J.; Harris, H.E.; Ulfgren, A.K.; Rantapaa-Dahlqvist, S.; et al. A new model for an etiology of rheumatoid arthritis: Smoking may trigger HLA-DR (shared epitope)-restricted immune reactions to autoantigens modified by citrullination. Arthritis Rheum. 2006, 54, 38-46. [CrossRef] [PubMed]

117. Van der Helm-van Mil, A.H.; Verpoort, K.N.; le, C.S.; Huizinga, T.W.; de Vries, R.R.; Toes, R.E. The HLA-DRB1 shared epitope alleles differ in the interaction with smoking and predisposition to antibodies to cyclic citrullinated peptide. Arthritis Rheum. 2007, 56, 425-432. [CrossRef] [PubMed]

118. Kallberg, H.; Padyukov, L.; Plenge, R.M.; Ronnelid, J.; Gregersen, P.K.; van der Helm-van Mil, A.H.; Toes, R.E.; Huizinga, T.W.; Klareskog, L.; Alfredsson, L. Gene-gene and gene-environment interactions involving HLA-DRB1, PTPN22, and smoking in two subsets of rheumatoid arthritis. Am. J. Hum. Genet. 2007, 80, 867-875. [CrossRef] [PubMed]

119. Wesoly, J.; van der Helm-van Mil, A.H.; Toes, R.E.; Chokkalingam, A.P.; Carlton, V.E.; Begovich, A.B.; Huizinga, T.W. Association of the PTPN22 C1858T single-nucleotide polymorphism with rheumatoid arthritis phenotypes in an inception cohort. Arthritis Rheum. 2005, 52, 2948-2950. [CrossRef] [PubMed]

120. Plenge, R.M.; Seielstad, M.; Padyukov, L.; Lee, A.T.; Remmers, E.F.; Ding, B.; Liew, A.; Khalili, H.; Chandrasekaran, A.; Davies, L.R.; et al. TRAF1-C5 as a risk locus for rheumatoid arthritis-A genomewide study. N. Engl. J. Med. 2007, 357, 1199-1209. [CrossRef] [PubMed] 
121. Lorentzen, J.C.; Flornes, L.; Eklow, C.; Backdahl, L.; Ribbhammar, U.; Guo, J.P.; Smolnikova, M.; Dissen, E.; Seddighzadeh, M.; Brookes, A.J.; et al. Association of arthritis with a gene complex encoding C-type lectin-like receptors. Arthritis Rheum. 2007, 56, 2620-2632. [CrossRef] [PubMed]

122. Sigurdsson, S.; Padyukov, L.; Kurreeman, F.A.; Liljedahl, U.; Wiman, A.C.; Alfredsson, L.; Toes, R.; Ronnelid, J.; Klareskog, L.; Huizinga, T.W.; et al. Association of a haplotype in the promoter region of the interferon regulatory factor 5 gene with rheumatoid arthritis. Arthritis Rheum. 2007, 56, 2202-2210. [CrossRef] [PubMed]

123. Arnson, Y.; Shoenfeld, Y.; Amital, H. Effects of tobacco smoke on immunity, inflammation and autoimmunity. J. Autoimmun. 2010, 34, J258-J265. [CrossRef] [PubMed]

124. Anzilotti, C.; Merlini, G.; Pratesi, F.; Tommasi, C.; Chimenti, D.; Migliorini, P. Antibodies to viral citrullinated peptide in rheumatoid arthritis. J. Rheumatol. 2006, 33, 647-651. [PubMed]

125. Burkhardt, H.; Sehnert, B.; Bockermann, R.; Engstrom, A.; Kalden, J.R.; Holmdahl, R. Humoral immune response to citrullinated collagen type II determinants in early rheumatoid arthritis. Eur. J. Immunol. 2005, 35, 1643-1652. [CrossRef] [PubMed]

126. Kinloch, A.; Tatzer, V.; Wait, R.; Peston, D.; Lundberg, K.; Donatien, P.; Moyes, D.; Taylor, P.C.; Venables, P.J. Identification of citrullinated alpha-enolase as a candidate autoantigen in rheumatoid arthritis. Arthritis Res. Ther. 2005, 7, R1421-R1429. [CrossRef] [PubMed]

127. Pratesi, F.; Tommasi, C.; Anzilotti, C.; Chimenti, D.; Migliorini, P. Deiminated Epstein-Barr virus nuclear antigen 1 is a target of anti-citrullinated protein antibodies in rheumatoid arthritis. Arthritis Rheum. 2006, 54, 733-741. [CrossRef] [PubMed]

128. Sebbag, M.; Moinard, N.; Auger, I.; Clavel, C.; Arnaud, J.; Nogueira, L.; Roudier, J.; Serre, G. Epitopes of human fibrin recognized by the rheumatoid arthritis-specific autoantibodies to citrullinated proteins. Eur. J. Immunol. 2006, 36, 2250-2263. [CrossRef] [PubMed]

129. Takizawa, Y.; Suzuki, A.; Sawada, T.; Ohsaka, M.; Inoue, T.; Yamada, R.; Yamamoto, K. Citrullinated fibrinogen detected as a soluble citrullinated autoantigen in rheumatoid arthritis synovial fluids. Ann. Rheum. Dis. 2006, 65, 1013-1020. [CrossRef] [PubMed]

130. Van der Woude, D.; Rantapaa-Dahlqvist, S.; Ioan-Facsinay, A.; Onnekink, C.; Schwarte, C.M.; Verpoort, K.N.; Drijfhout, J.W.; Huizinga, T.W.; Toes, R.E.; Pruijn, G.J. Epitope spreading of the anti-citrullinated protein antibody response occurs before disease onset and is associated with the disease course of early arthritis. Ann. Rheum. Dis. 2010, 69, 1554-1561. [CrossRef] [PubMed]

131. Dam, C.E.; Houen, G.; Trier, N.H. The dependency on neighboring amino acids for reactivity of anti-citrullinated protein antibodies to citrullinated proteins. Scand. J. Clin. Lab. Investig. 2016, 76, 417-425. [CrossRef] [PubMed]

132. Lundberg, K.; Kinloch, A.; Fisher, B.A.; Wegner, N.; Wait, R.; Charles, P.; Mikuls, T.R.; Venables, P.J. Antibodies to citrullinated alpha-enolase peptide 1 are specific for rheumatoid arthritis and cross-react with bacterial enolase. Arthritis Rheum. 2008, 58, 3009-3019. [CrossRef] [PubMed]

133. Trier, N.H.; Leth, M.L.; Hansen, P.R.; Houen, G. Cross-reactivity of a human IgG(1) anticitrullinated fibrinogen monoclonal antibody to a citrullinated profilaggrin peptide. Protein Sci. 2012, 21, 1929-1941. [CrossRef] [PubMed]

134. Union, A.; Meheus, L.; Humbel, R.L.; Conrad, K.; Steiner, G.; Moereels, H.; Pottel, H.; Serre, G.; de Keyser, F. Identification of citrullinated rheumatoid arthritis-specific epitopes in natural filaggrin relevant for antifilaggrin autoantibody detection by line immunoassay. Arthritis Rheum. 2002, 46, 1185-1195. [CrossRef] [PubMed]

135. Trier, N.H.; Dam, C.E.; Olsen, D.T.; Hansen, P.R.; Houen, G. Contribution of Peptide Backbone to Anti-Citrullinated Peptide Antibody Reactivity. PLoS ONE 2015, 10, e0144707. [CrossRef] [PubMed]

136. Trier, N.H.; Holm, B.E.; Slot, O.; Locht, H.; Lindegaard, H.; Svendsen, A.; Houen, G. Physical characteristics of a citrullinated pro-filaggrin epitope recognized by anti-citrullinated protein antibodies in rheumatoid arthritis sera. PLoS ONE 2016, 11, e0168542. [CrossRef] [PubMed]

137. Babos, F.; Szarka, E.; Nagy, G.; Majer, Z.; Sarmay, G.; Magyar, A.; Hudecz, F. Role of N- or C-terminal biotinylation in autoantibody recognition of citrullin containing filaggrin epitope peptides in rheumatoid arthritis. Bioconjug. Chem. 2013, 24, 817-827. [CrossRef] [PubMed] 
138. Pratesi, F.; Tommasi, C.; Anzilotti, C.; Puxeddu, I.; Sardano, E.; Di, C.G.; Migliorini, P. Antibodies to a new viral citrullinated peptide, VCP2: Fine specificity and correlation with anti-cyclic citrullinated peptide (CCP) and anti-VCP1 antibodies. Clin. Exp. Immunol. 2011, 164, 337-345. [CrossRef] [PubMed]

139. Wood, D.D.; Ackerley, C.A.; Brand, B.; Zhang, L.; Raijmakers, R.; Mastronardi, F.G.; Moscarello, M.A. Myelin localization of peptidylarginine deiminases 2 and 4: Comparison of PAD2 and PAD4 activities. Lab. Investig. 2008, 88, 354-364. [CrossRef] [PubMed]

140. Kobylyansky, A.G.; Nekrasov, A.N.; Kozlova, V.I.; Sandin, M.Y.; Alikhanov, B.A.; Demkin, V.V. Detection of new epitopes of antibodies to filaggrin in filaggrin protein molecule. Bull. Exp. Biol. Med. 2011, 151, 615-618. [CrossRef] [PubMed]

141. Dorow, D.S.; Shi, P.T.; Carbone, F.R.; Minasian, E.; Todd, P.E.; Leach, S.J. Two large immunogenic and antigenic myoglobin peptides and the effects of cyclisation. Mol. Immunol. 1985, 22, 1255-1264. [CrossRef]

142. Nair, D.T.; Singh, K.; Siddiqui, Z.; Nayak, B.P.; Rao, K.V.; Salunke, D.M. Epitope recognition by diverse antibodies suggests conformational convergence in an antibody response. J. Immunol. 2002, 168, 2371-2382. [CrossRef] [PubMed]

143. Ioan-Facsinay, A.; el-Bannoudi, H.; Scherer, H.U.; van der Woude, D.; Menard, H.A.; Lora, M.; Trouw, L.A.; Huizinga, T.W.; Toes, R.E. Anti-cyclic citrullinated peptide antibodies are a collection of anti-citrullinated protein antibodies and contain overlapping and non-overlapping reactivities. Ann. Rheum. Dis. 2011, 70, 188-193. [CrossRef] [PubMed]

144. Willemze, A.; Bohringer, S.; Knevel, R.; Levarht, E.W.; Stoeken-Rijsbergen, G.; Houwing-Duistermaat, J.J.; van der Helm-van Mil, A.H.; Huizinga, T.W.; Toes, R.E.; Trouw, L.A. The ACPA recognition profile and subgrouping of ACPA-positive RA patients. Ann. Rheum. Dis. 2012, 71, 268-274. [CrossRef] [PubMed]

145. Montes, A.; Perez-Pampin, E.; Calaza, M.; Gomez-Reino, J.J.; Gonzalez, A. Association of anti-citrullinated vimentin and anti-citrullinated alpha-enolase antibodies with subsets of rheumatoid arthritis. Arthritis Rheum. 2012, 64, 3102-3110. [CrossRef] [PubMed]

146. Goldbach-Mansky, R.; Lee, J.; McCoy, A.; Hoxworth, J.; Yarboro, C.; Smolen, J.S.; Steiner, G.; Rosen, A.; Zhang, C.; Menard, H.A.; et al. Rheumatoid arthritis associated autoantibodies in patients with synovitis of recent onset. Arthritis Res. 2000, 2, 236-243. [CrossRef] [PubMed]

147. Goules, J.D.; Goules, A.V.; Tzioufas, A.G. Fine specificity of anti-citrullinated peptide antibodies discloses a heterogeneous antibody population in rheumatoid arthritis. Clin. Exp. Immunol. 2013, 174, 10-17. [CrossRef] [PubMed]

(C) 2017 by the authors. Licensee MDPI, Basel, Switzerland. This article is an open access article distributed under the terms and conditions of the Creative Commons Attribution (CC BY) license (http://creativecommons.org/licenses/by/4.0/). 